\title{
Working
}

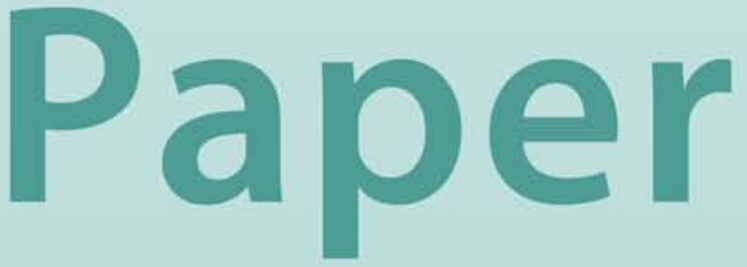




\title{
Exchange Rate Choices of Microstates
}

\author{
Patrick Imam
}




\title{
IMF Working Paper
}

\author{
Monetary and Capital Markets Department
}

\section{Exchange Rate Choices of Microstates}

\section{Prepared by Patrick Imam ${ }^{1}$}

\author{
Authorized for distribution by Carlos Medeiros
}

January 2010

\begin{abstract}
This Working Paper should not be reported as representing the views of the IMF. The views expressed in this Working Paper are those of the author and do not necessarily represent those of the IMF or IMF policy. Working Papers describe research in progress by the authors and are published to elicit comments and further debate.
\end{abstract}

In this paper we first explain why most microstates (countries with less than 2 million inhabitants) have gained independence only in the last 30 years. Despite the higher costs and risks microstates face, their ability to better accommodate local preferences combined with a more integrated world economy probably explains why the benefits of independence have risen. We explain why microstates at independence have chosen either dollarization, currency board arrangements, or fixed exchange rates rather than more flexible forms of exchange rate systems. We then, using the Geweke-Hajvassiliou-Keane multivariate normal simulator, model empirically the determinants of each of the different fixed exchange rate regimes in microstates and analyze the policy implications.

JEL Classification Numbers:E42, E52, F33

Keywords: Micro-states, Dollarization, Currency board, Fixed exchange rate, GewekeHajivassiliou-Keane Multivariate Simulator

Author's E-Mail Address:pimam@imf.org

\footnotetext{
${ }^{1}$ I would like to thank Prasad Bhattacharya, Philippe Callier, Martin Cihak, Dale Gray, Kangi Kpodar, Pamela Madrid, Paul Mathieu, Carlos Medeiros, Camelia Minoiu, Mahvash Qureshi, Scott Roger, Heidi Ryoo, Issouf Samake, Kenneth Train and Romain Veyrune for useful comments. This paper was presented at the Australasian Macroeconomic Workshop held in Melbourne April 14-15, 2009. The usual disclaimer applies.
} 


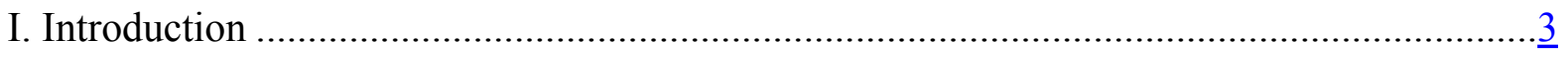

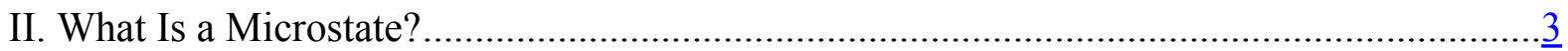

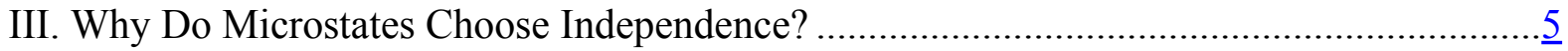

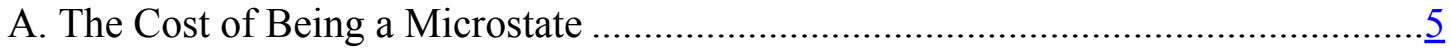

Higher Costs............................................................................. $\frac{5}{5}$

Higher Risks................................................................................ $\frac{7}{7}$

B. The Benefits of Being a Microstate.................................................................... $\frac{8}{8}$

Better Accommodation of Preferences .................................................. $\underline{8}$

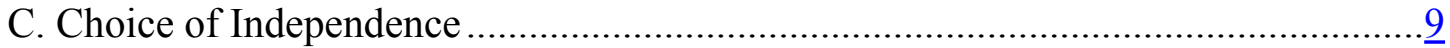

IV. Choosing Exchange Rate Policy in Microstates .......................................................... 11

A. Problems of Floating Exchange Rate in Microstates ........................................ $\frac{12}{15}$

B. Advantages of Hard Pegs in Microstates ........................................................ 15

V. Why Do Microstates Choose a Given Form of Hard Peg? ......................................... 17

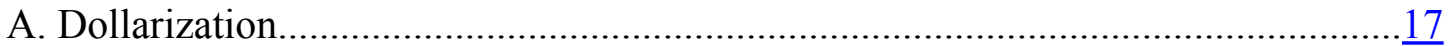

B. Currency Board Arrangements......................................................................... $\frac{19}{21}$

C. Fixed Exchange Rates .........................................................................

D. How Do the Different Hard Pegs Compare? ...................................................

VI. Econometric Estimation..................................................................................... 27

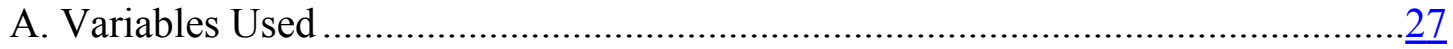

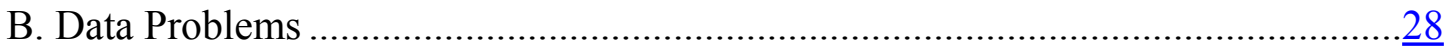

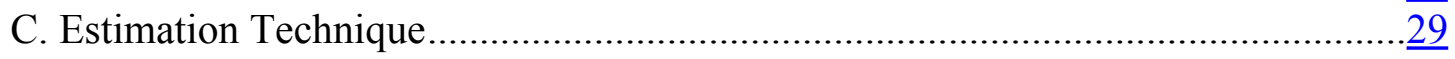

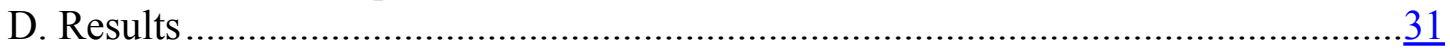

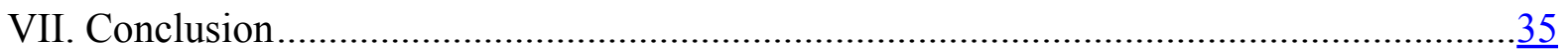

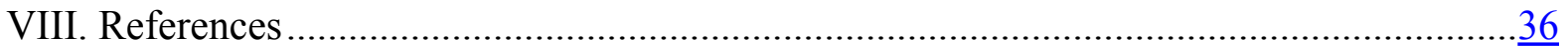




\section{INTRODUCTION}

Although the median population of all the countries in the world is about 5 million people, country populations vary tremendously. Giant countries like China and India, with over 1 billion inhabitants each, exist side by side with states like Anguilla or Tuvalu that have fewer than 50,000 inhabitants. States with fewer than 2 million inhabitants are referred to as microstates. ${ }^{2}$ Their number rose rapidly in the last decades of the $20^{\text {th }}$ century, not because of population changes and migration but, as we will illustrate, due to increases in the number of lightly populated territories choosing to become independent.

After reviewing why microstates choose to become independent, despite the fact that most economic arguments would suggest they might be better off as part of a larger country, we look at an aspect that to our knowledge has not yet been addressed in the economic literature: How do microstates choose their exchange rate regime? After independence the vast majority of these countries adopted hard pegs, but these vary. Some have fully dollarized, others have used currency boards, and others have gone for fixed exchange rates. This paper analyzes what determines this decision.

In what follows, Section II defines and discusses "microstates." Section III discusses the disadvantages of being a microstate - higher costs and risk — and the advantages - a government more responsive to local preferences. We show that, thanks to globalization, changes in the cost-benefit balance in the last three decades of the $20^{\text {th }}$ century made statehood more attractive. After discussing the factors involved in choosing an exchange rate policy in Section IV, in Section V we describe which microstates have chosen dollarization, which currency board arrangements (CBAs), and chosen fixed exchange rates, and compare the pros and cons of each system. In Section VI, using the Geweke-Hajvassiliou-Keane multivariate normal simulator we analyze the determinants of each of these fixed exchange rate regimes in micro-state. Section VII we draw conclusions.

\section{What Is a Microstate?}

Microstates for our purposes are independent territories with less than 2 million inhabitants. By this measure, there are about 50 microstates, two-thirds of them island economies. Microstates are mainly located in the Caribbean region, around the African coast, and in the Pacific. We do not consider dependent territories of countries like the United Kingdom, even though, like the Falkland Islands, they may have considerable autonomy; because they are not fully independent they lack the national account data essential to our analysis.

One major commonality of microstates, besides being lightly populated, is that they are relatively young states; most of them having been formed since World War II and notably after most of the decolonization period in sub-Saharan Africa had ended. Many microstates

\footnotetext{
${ }^{2}$ In this paper, except where explicitly mentioned, size of a country will refer to the size of the population, not to its geographical or economic size.
} 
have been created since the mid-1970s (see Figure 1). We will explore below why independence has been a recent choice.

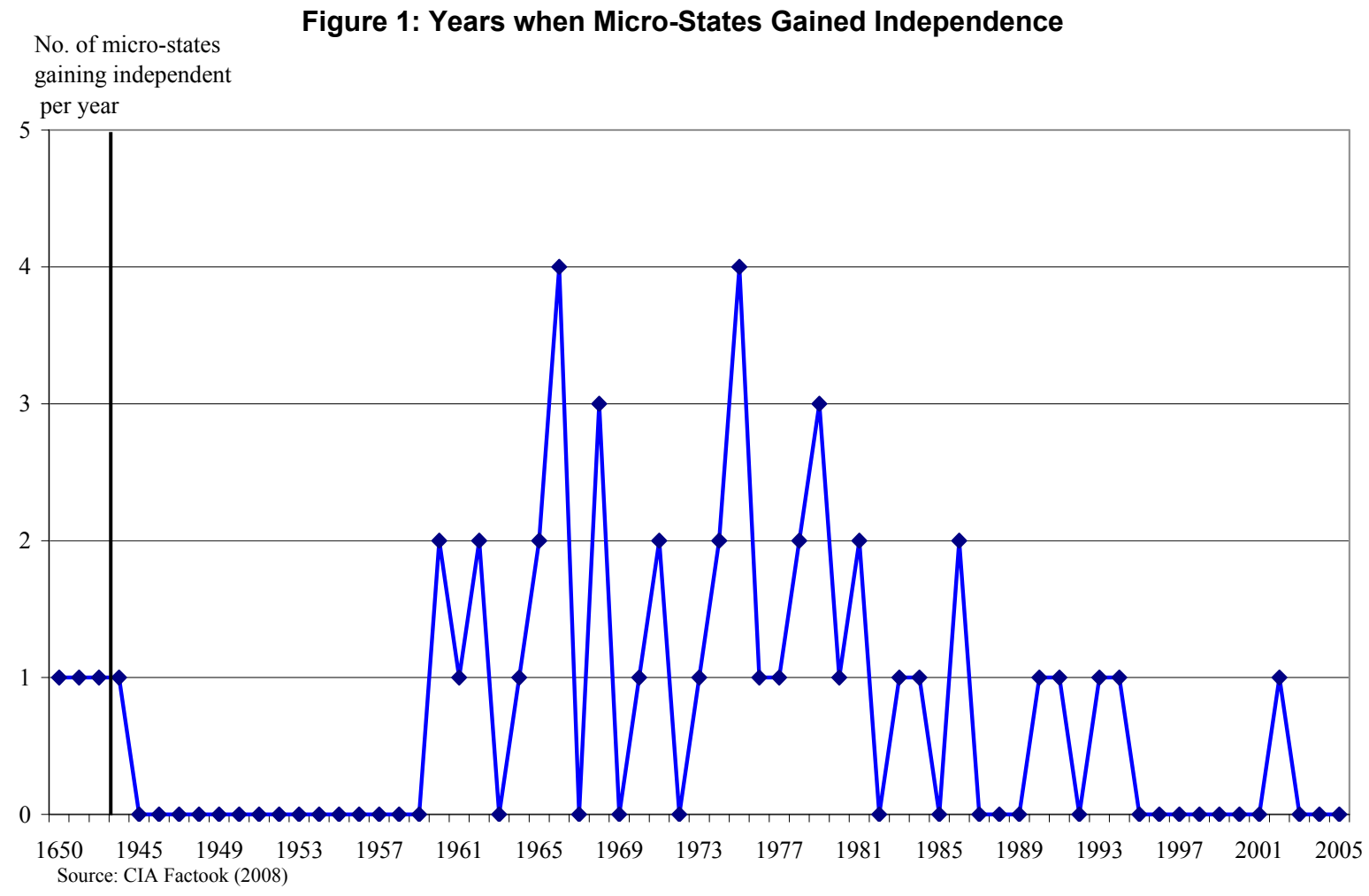

While having some commonalities, microstates are also quite diverse. Some are very rich (the Bermudas), some very poor (Guinea-Bissau). ${ }^{3}$ Some are islands (Malta), some part of the mainland (Bahrain). ${ }^{4}$ Some have natural resources (Kuwait); some have none (Belize). Some were former French colonies (Djibouti), most were former British colonies (most Caribbean countries). Some became independent in the $19^{\text {th }}$ century (in the Caribbean), some not until the current century (Timor-Leste, 2002). Some have homogenous populations (Malta); some are very heterogeneous (Fiji). Some microstates were uninhabited until European colonizers arrived (Mauritius); most of these were populated with either white settlers (Falkland Islands) or indentured labor (Caribbean region). Some microstates, notably in the Pacific, were already populated but still witnessed the arrival of white settlers and indentured labor, often from India (see Appendix 1 for a summary of the history of micro-states).

\footnotetext{
${ }^{3}$ Some authors (e.g., Armstrong et al., 1998) estimate that microstates are richer on average than other states, implying that small size is not a barrier to wealth. We consider this finding questionable. Many islands in the Caribbean and the Pacific ocean have attracted billionaires and rich retired people because of favorable tax policies and good weather. These outliers drive up income per capita: when Bill Gates enters a restaurant, the average person in that restaurant becomes a millionaire, and if the restaurant contains only a few people, even a billionaire.

${ }^{4}$ Some of the islands are archipelagos, spread across hundreds of miles, particularly in the Pacific, and some are mountainous. Geography can raise transportation costs.
} 


\section{Why Do Microstates ChOOSE IndePENDENCE?}

In theory microstates could be the result of geography, but in reality borders are not exogenously specified. Most microstates, like other states, are largely the result of policy choices. While political factors are the ultimate force behind whether a microstate decides to become independent, the decision is typically underlined by a cost-benefit analysis. Below we explore these costs and benefits and explain why the late independence of many microstates may be explained by shifts in the cost-benefit ratio. We will document the two main disadvantages of microstates compared to larger states: higher costs, broadly defined, and more risk. However, the benefit of a microstate is that it better accommodates the preferences of the local population.

\section{A. The Cost of Being a Microstate}

\section{Higher Costs}

The per capita cost of supplying public goods is higher in microstates than in larger countries due to the lack of economies of scale in the supply of public goods (Alesina and Wacziarg, 1998). This applies to all forms of public goods, from the courts, infrastructure, police, and health care to tax collection agencies. ${ }^{5}$

Besides higher costs per capita, the quality of public goods is likely to be inferior in microstates. Smallness means that a critical domestic supply of labor is lacking, especially of those with specialized skills. For example, if a country needs to appoint a competition commissioner (the same presumably would apply to regulators), a highly specialized skill, and does not have a domestic talent pool from which to recruit such a person, it will either have to import the skill from abroad, at high cost, or forgo this function altogether.

Another problem for microstates is that the public administration is subject to more pressure. Farrugia (1993) documents how pressures on civil servants in microstates are proportionately higher than in larger states. Limited human capital means that civil servants must perform multiple functions that dilute their ability to acquire focused expertise; have more interpersonal relationships with the rest of the population, which may lead to more corruption; ${ }^{6}$ and have fewer advancement opportunities because the state is small, which could be demoralizing. ${ }^{7}$

\footnotetext{
${ }^{5}$ One public good that is often not supplied at all in microstates is defense, as we explain below.

${ }^{6}$ The rule of law is more difficult to apply in microstates because representatives of the law-judges, police officers - interact continuously with guilty parties both before and after the law has been applied. In this environment, 'retaliation,' broadly defined, is more likely. For instance, a police officer who fines a restaurant owner for a traffic violation might not be well served in that establishment thereafter.

${ }^{7}$ Microstates might not even be able to develop a critical mass in specialized industries, simply because of this labor constraint.
} 
The labor force is often segmented in microstates, with the expatriate population being relatively flexible and the indigenous population relatively inflexible. Expatriates, who work mainly in positions that are either highly skilled (e.g., doctors, bankers, managers) or lowskilled (e.g., construction workers), are relatively flexible; they often come on a temporary contract or are subject to very flexible labor laws. Typically, the indigenous labor force in microstates tends to be highly protected, or custom makes it socially difficult for private sector managers to fire them. This creates a highly inflexible indigenous labor force, which tends to be employed mainly in the administration, parastatals, or other relatively secure jobs. As a result, in microstates often a large chunk of the indigenous population is not employable by market standards, and there is high unemployment or underemployment. The public administration often then acts as the employer of last resort and the bureaucracy becomes overstaffed with poorly trained individuals (see also Rodrik, 1998).

Another result of the high administrative costs is that microstates will tend to go for cheaper though socially more distortionary institutional features. Easterly and Rebelo (1993) find that, after controlling for income, countries with larger populations rely on more efficient forms of taxation, such as income tax or value-added taxes (VAT), rather than less efficient and more distortionary income sources, such as custom taxes. Hines and Summers (2009), using an unbalanced panel of mainly OECD countries for 1972-2006, find evidence that a 10 percent decline in the population is associated with a 1 percent lower ratio of income taxes to total tax revenues. One reason is that it is costlier to set up the bureaucracy for income and corporate tax units than for collecting custom duties. Similarly, microstates are likely to have relatively more mobile tax bases and, therefore, rely more on consumption-type taxes, such as expenditure taxes or import tariffs.

Besides higher institutional costs, microstates face higher trade costs (see Imam, 2008) and pay more for tradables. Distance from major markets, which raises transportation costs, is often a peculiarity of microstates other than those in the Caribbean region. Pacific Islands and microstates in and around Africa are often dependent on adjacent states for port and communication facilities. By acting like a tax, this increases the trade hurdle, penalizing exports and making imports dearer. ${ }^{8}$ A large unified state, on the other hand, would guarantee free trade among its regions. In principle, in a borderless world with no obstacles to free trade in factors of production, being an independent country does not matter. Empirically, though, McCallum (1995) famously illustrated that even though distance is a major factor in trade flows, all else being equal two distant Canadian provinces trade much more with each other than with the United States and Canadian provinces that border each other. This suggests that microstates might lose some trade flows compared to what would happen if they were part of

\footnotetext{
${ }^{8}$ A related geographical problem is a lack of natural endowments in most microstates. A small population is with certain exceptions correlated with small geographical size. The local resource base of most microstates is often constrained by limited geographical area and natural endowments. Moreover, because most microstates do not produce manufactured goods or produce, ships enter the ports with full containers but leave with empty ones, which adds to transportation costs.
} 
a larger country. In other words, borders are costly, and economic interactions within countries are easier than between countries. Therefore, even with free trade, because of market barriers like differences in language, currency, or the legal basis for enforcing contracts, national borders add to trade costs.

A small domestic market is likely to inhibit competition due to the invisibility of production and the small number of firms, leading to a rise in both tradable and nontradable costs (because tradables are inputs into nontradables and vice versa) (see Easterly and Kraay, 2000). Therefore, costs in microstates are in general higher than in larger countries.

\section{Higher Risks}

Microstates face higher risks than larger states. One of them is more volatile terms of trade. Because its domestic markets are small, a microstate's economy is likely to be very open but capable of producing only a few goods and services. Microstates are more vulnerable to terms of trade changes because they have to import most of their necessities, from food to manufactures, for which demand is highly inelastic, and they have a very limited range of export earning potential (see Imam, 2008). This leads to more volatility in growth rates.

Another risk for microstates is the lack of regional insurance. In a large state, risks (e.g., weather-related) are less likely to be correlated than in smaller states because there is more geographic dispersion. The lack of a diversification effect increases the vulnerability of microstates (see Easterly and Kraay, 2000). This is especially a problem if imperfect capital markets do not allow for insurance. ${ }^{9}$ Similarly, the redistribution schemes from richer to poorer regions that are available in larger states are not available in microstates, again raising risk.

Microstates are likely to be less able to internalize externalities that affect neighboring countries than if they were part of a large state due to free-rider problems ("the commons problem"). For example, if each microstate in adjacent territorial waters were to decide its own fishing policy, the result would be over-fishing. A large country would more easily internalize the problem because the long-term benefits would accrue to the whole state. Microstates face this prisoner's dilemma; as long as they lack enforceable institutional mechanisms, they are likely to overfish (see also Alesina and Spolaore, 2003).

Another risk for microstates is foreign aggression. Because their populations are small, all else being equal, microstates are less able protect themselves from foreign aggressors because military size is typically a function of population size (as well as income and the aggressiveness of neighbors). Thus microstates need to spend more as a share of GDP to get the same deterrent effect as larger states. While theoretically this is a risk, in practice it is likely to be minor, because microstates do not in general spend much on their military and

\footnotetext{
${ }^{9}$ The introduction of CATS (catastrophic bonds) provided a financial product that can help insure against such problems, though the high cost means that it is only accessible for richer microstates.
} 
may not even have an army. This is not only because of the low perception of external threat but also because there is an implicit, if not explicit, territorial guarantee from former colonizers. However, this comes at a cost. For instance, a corollary of this guarantee could be that microstates are implicitly expected to vote with their protectors on $\mathrm{UN}$ resolutions.

\section{B. The Benefits of Being a Microstate}

\section{Better Accommodation of Preferences}

The benefits of being a microstate are less clear-cut than the costs and tend to relate mainly to better accommodation of differences in preferences of its population compared with the colonizing state of which they were once a part.

Large countries are likely to be more heterogeneous in terms of redistributive preferences. If the median voters in a territory that later chooses to be a microstate have different preferences than the population of the large unified state, they will be less satisfied by the central government. For instance, individuals in a micro colony that are much richer than their colonial masters might favor higher income tax rates, and those that are much poorer might favor lower rates. ${ }^{10}$ The median voter in each region will have different preferences, which might be problematic when tax rates are applied equally across the whole population. Therefore, independence might be beneficial to microstates if voters put more weight on the "government being closer to the people" than on the efficiency benefits of the union (Bolton and Roland, 1997).

Besides having different preferences for taxes and government spending, regions might have other differences that could explain the desire to gain independence. Alesina and Spolaore (2003) have shown ethnolinguistic fractionalization to be inversely related to economic success and to different measures of quality of government. Independence, by making countries more homogenous, could make the government more responsive to the needs of the domestic population and could explain why microstates demand independence. Many microstates have a different racial make-up than the original colonizing country. As a result, they may have had different preferences from, and less allegiance to, the colonizing country than potential microstates that more closely resemble the colonizer.

This could explain why most microstates were formerly British, which were often racially and culturally less connected to Britain, while French colonies often had a large stock of people directly descendent from mainland France (see Box 1). ${ }^{11}$

\footnotetext{
${ }^{10}$ Bolton and Roland (1997) make the case that "regions with very low income inequality may want to break away from a nation with high income inequality and high tax rates in order to impose lower tax rates, and vice versa a region with high income inequality may want to separate in order to impose more redistribution than in the unified country" (p. 1059).

${ }^{11}$ Another argument for microstates is that there are diseconomies of scale in the provision of administrative goods. While this argument is true for large states, it is doubtful for microstates that are so small to begin with.
} 


\section{Box 1: Colonizers of Microstates}

Most microstates become independent from the U.K., followed by Portugal, the Netherlands, France, and the U.S. The microstates that achieved independence from the U.S. were primarily U.S.-administered U.N. trusteeships (e.g., Palau, the Federated States of Micronesia) rather than colonies in the traditional sense. While over the centuries both the U.K. and France colonized many islands, far more microstates became independent from the U.K. than from France. Why did the Seychelles and Mauritius become independent, but not La Reunion? Why did Guadeloupe stay French, but not Trinidad and Tobago? Why did Tahiti stay French, but not Fiji? There are several possible explanations. The British may have made it easier for countries to become independent, or the French made it less appealing (e.g., by continuing to transfer money to overseas territories), or a combination of both.

\section{Chart 1: Colonizer of Micro-States}

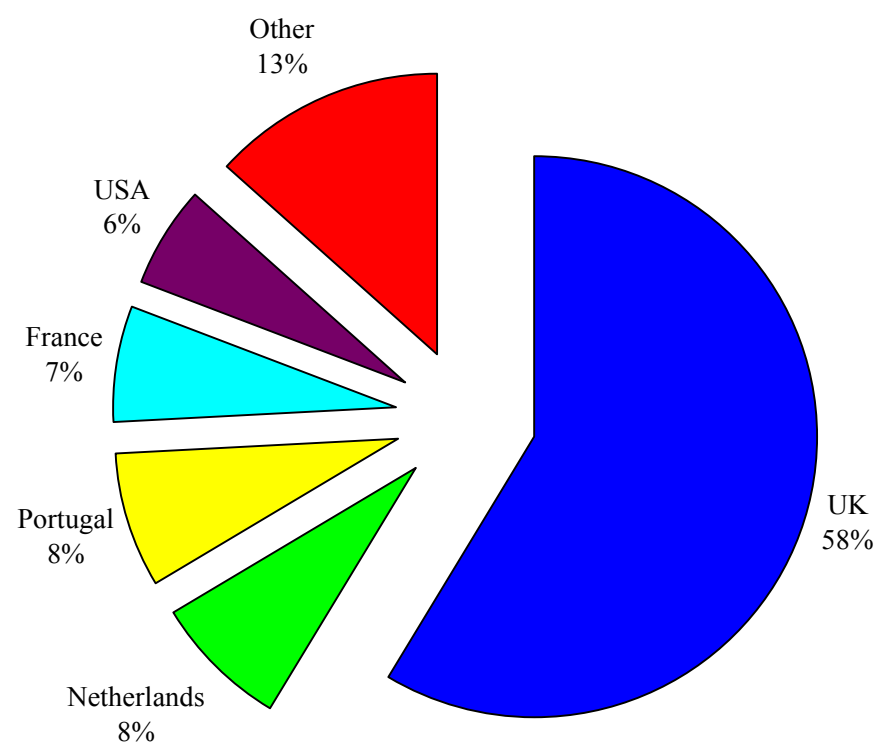

Source: CIA Factook (2008)

The French-administered territories outside the European continent, the DOM-TOMs ("départements d'outre-mer, territoires d'outre-mer") have varying degrees of autonomy, while continuing to be represented in the French parliament and being beneficiaries of certain subsidies that they would forgo if they were not part of France. The British do not have such generous arrangements. The Commonwealth provides few financial benefits. It does provide a forum, however, in which the U.K. listens to the needs of its former colonies, and this special relationship might be a reason why the political costs of gaining independence might not be high for these microstates: they perceive that the U.K. will continue to defend their interests on the international stage. Moreover, the settlements of many DOM-TOMs are made up of a large share of "French stock," that still has close connections to the French mainland. The settlers of former British colonies, on the other hand, more often reflect a resettlement of African, Asian, or natives of other colonies that have weak historical links to the U.K. and hence less allegiance to the U.K. 


\section{Choice of Independence}

If at least theoretically the disadvantages appear to outweigh the advantages, why do microstates demand independence? Many microstates are relatively young, having come into existence only since the 1960s. Our contention is that the costs of being a microstate have fallen over time and the benefits have risen, making independence more attractive. Nor are the benefits and costs necessarily purely pecuniary; they may reflect nonmonetary benefits, such as self-determination.

Some of the initial benefits of being part of a larger state may no longer hold. Rising fiscal pressures at home have, over the years, forced former colonizing powers like Britain to cut their spending on their overseas territories. Therefore the fiscal cost of becoming independent in terms of forgone revenues from the metropolis has fallen. The benign neglect to which microstates felt they were subject, particularly in the 1960s and 1970s after the economic crisis in many former colonizing powers, also meant that the colonies lost interest in the former master.

Unlike most countries, which had to fight for independence by resorting to arms, with notable exceptions like Eritrea and several former Portuguese colonies, microstates were able to achieve independence without violence. The cost in terms of lives lost and physical destruction was therefore nonexistent, making independence easier and cheaper.

In a world where punishing aggressors for violating national sovereignty is becoming more important (e.g., Kuwait), the defense argument for being part of a large country matters less in most regions of the world.

In an increasingly open world with falling trade barriers, being part of a country that is very far away may make less sense. Most of the benefits of trade can, in principle, be achieved by being independent (Alesina and Spolaore, 2003). ${ }^{12}$ With falling transport costs and more liberalized trade, the economic costs of being a microstate diminish. That is not to endorse the view that in a borderless world with no obstacles to free trade in factors of production, country size does not matter. The findings of McCallum (1995), cited earlier, suggests that some latent factor inhibits (micro-)states from trading as much when they are independent as when they are part of a larger country. Nonetheless, larger states are willing to grant microstates special assistance — such as preferential agreements like the Cotonou and Lomé Agreements with the European Union (EU) or the more recent Economic Partnership Agreements - that acts like a subsidy to their export sectors and eliminates most of the costs of not being part of a larger state.

\footnotetext{
${ }^{12}$ History is full of examples of microstates that achieved prosperity. The city-states of Italy, the Hanseatic Cities, and the Low Countries during the Renaissance are examples of microstates that prospered by taking advantage of free European trade. In this period city states did not provide many public goods, so there were no large economies of scale in provision of public goods, such as military technology, which at the time still had no large economies of scale (see Alesina and Spolaore, 2003).
} 
Thus an increasingly open world — with falling visible and invisible barriers; technology that makes distance less costly; and preferential trade agreements - has improved the appeal of microstatehood.

\section{Choosing Exchange Rate Policy in Microstates}

With independence one of the most important macroeconomic decisions microstates face is which exchange rate system to adopt. Although economists tend to view it as natural that each country maintains its own "territorial" currency, historically there is nothing natural about it. Territorial currencies started only in the $19^{\text {th }}$ century and became the standard for most countries only at some point in the $20^{\text {th }}$ century (Ruggie, 1993). Until then, monetary structures around the world differed substantially. For example, foreign currencies circulated easily alongside domestic currencies and often territories were part of some type of monetary union. Before independence microstates virtually always used the currency of the former colonial power, or where there was a currency board made it the reserve currency (see more below). Why would a microstate want to choose its own territorial currency after gaining independence?

The creation of a territorial currency can help strengthen national identity in a new state. "Because trust plays such a large role in the use and acceptance of modern forms of money, it [is] thought that territorial currencies might encourage identification with the nation-state at a deeper psychological level" (Helleiner, 2004, p. 11).

Moreover, a territorial currency provides for seignorage, thereby creating a source of revenue for the ministry of finance that can be important for countries with few income sources. Seignorage - which in a typical microstate such as Cape Verde has been estimated at close to 1 percent of GDP per annum (see Imam, 2009) — is especially important where the government cannot easily borrow, and the tax authority is underdeveloped.

By making a clear distinction between domestic and foreign currency, policymakers hope that the new currency, which increases transaction costs by creating an exchange rate risk, will allow for more macroeconomic activism, and state-led economic development. In particular, a territorial currency that is not pegged allows a country to adopt an independent monetary policy. This may help alleviate the business cycle and reduce volatility; for instance, in a slowdown a microstate could reduce interest rates. Similarly, tight international credit markets can be circumvented if the central bank can increase money supply. ${ }^{13}$

\footnotetext{
${ }^{13}$ It is not clear whether a microstate can really benefit from proactive macro policies. The history of floating exchange rates for most developing countries has been poor. Until the early 20th century most developing countries, at the time still colonies, did not have central banks but had either notes issued by private commercial banks, as in Latin America, or currency boards, as in most self-governing British colonies (Schuler, 1992). Most of the countries experienced rising inflation and limited currency convertibility after they created a domestic currency. With destabilizing currencies, they also became net exporters of capital, for instance through capital flight.
} 
It was also expected, (perhaps naively), that a floating territorial currency would make an undiversified economy absorb (terms of trade) shocks via the exchange rate. To maintain employment or wages, a country could let its exchange rate depreciate. In hindsight, however, exchange rate devaluation, particularly in the context of a poor macroeconomic policy framework, often leads to instability, with for instance a macro-shock causing very high inflation.

Except for dollarized countries, for microstates that have chosen a territorial currency the question becomes whether to float or fix the exchange rate. We will show that microstates have mostly fixed rather than floated, mainly for good reasons.

\section{A. Problems of Floating Exchange Rate in Microstates}

At independence microstates mostly traded with the former colonial power, with trade invoiced in the colonial currency (or a currency board currency with the reserve currency being the former colonial currency). It requires political courage for a government to exit an exchange rate regime that is performing well because it adds to trade costs, and to prepare the steps to exit may lead to instability, if not crisis.

Another problem with a floating exchange rate is that a country needs to have in place the institutional infrastructure to operate monetary policy, in the form of a central bank with the necessary starting capital and, more important, the professional staff necessary to manage this institution, as well as to collect and analyze data. ${ }^{14}$ The classic pre-requisite for independent monetary policy is a fractional reserve banking system that allows the bank to affect the amounts of deposits and liquidity in the system. A well-functioning monetary policy based on the use of indirect instruments also requires a domestic financial systembut domestic fixed-income markets are shallow or nonexistent in microstates. Without liquid markets, selling government securities to manage liquidity cannot be done quickly without affecting their yields. The development of an interbank repo rate to allow the central bank to use its monetary operations more effectively is difficult if the banking system is oligopolistic, as it often is in microstates. This is confirmed by the work of Rogoff et al. (2003), who find that the benefits of more flexible exchange rate regimes increase as economies develop institutionally and become more integrated into global financial markets.

\footnotetext{
${ }^{14}$ What type of monetary policy should a central bank with a floating exchange rate choose? Typically, the decision requires targeting the monetary base or inflation, which creates the problems of defining the target and controlling it. If the central bank targets money supply, what measures of money supply does it target? It must control the measure it has chosen, set a target, achieve it, and regularly revise the target to take account of structural changes (e.g., new technologies) that can make money supply unpredictable. Problems of defining and achieving targets led most central banks in developed countries to abandon money supply targets in the 1980s. As microstates become more sophisticated, they could in principle move to inflation targeting. However, the institutional preconditions are important: policy must be transparent, there must be regular communication with the public, forecast models and information on the monetary transmission mechanism must be good, etc. Also, monetary policy has long lags, and the central bank has to act preemptively to reduce inflation. In microstates, the importance of exchange rate fluctuations for monetary policy changes cannot be ignored due to the high pass-through. This suggests that an inflation targeting microstate would probably have to manage the exchange rate in some way.
} 
In practice, because central banks in microstates lack credibility microstate monetary policy is likely to be procyclical, meaning that it cannot be used to smooth the business cycle or more generally for stabilization policies (Calvo and Reinhart, 2002). In practice, when external financing is abundant capital inflows surge, leading to exchange rate appreciation, and interest rates fall to minimize the appreciation. During crises, with capital flowing out the exchange rate depreciates and interest rates increase to support it. These procyclical swings in interest rates and the availability of external financing explain procyclical swings in capital inflows and is the opposite of how monetary policy should ideally work. Under the now widely used "Taylor rule," the central bank is supposed to increase interest rates when domestic demand is buoyant and inflation exceeds a previously announced target, and decrease them when demand cools and inflation falls below the target. Only if inflation is determined exclusively by aggregate demand is this rule countercyclical in microstates.

Similarly, the countercyclical effect of monetary policy is absent if the source of rising inflation is a supply shock, such as the surge in oil and food prices of 2005-08, because the fear of second-round effects may turn a supply shock into a permanent acceleration of inflation. To counteract inflationary pressure, interest rates must be increased. The central bank thus transforms the supply shock into a downswing in economic activity. Similarly, by trying to increase domestic interest rates during a positive supply shock, the central bank may induce additional capital inflows, which would reinforce the tendency of the exchange rate to appreciate. Joint appreciation and capital inflows can lead to a boom and low inflation, but only at the cost of growing external deficits that create vulnerability to a sudden stop in external financing. During downswings attempts to reduce the interest rate would induce additional capital outflows that would reinforce depreciation pressures. ${ }^{15}$ Active monetary policy is therefore unlikely to have a stabilizing impact on the economy of microstates.

Another problem of an independent monetary policy is that the transmission mechanism in microstates occurs mainly through its impact on the exchange rate and through balance sheet effects, not the lending channel, since financial markets are underdeveloped. In other words, monetary policy will be largely driven by exchange rate considerations. The interest rate pass-through on the economy is likely to be weak, reflecting shallow domestic markets, and the fact that borrowing for domestic investment (and consumption) is likely to be inelastic to interest rate changes. Banks typically will only lend to a captive market, which would comprise the government and large enterprises. Mortgage markets or loans to

\footnotetext{
${ }^{15}$ It is not clear even theoretically whether an independent monetary policy is desirable. The monetarist school, for instance, emphasizes that long and variable lags mean that the impact of monetary policy on the economy is not necessarily predictable (Laidler, 1982). The rational expectation school has argued that because people can anticipate monetary policy, it can only be effective if it acts via surprises. The problem is that surprises will destabilize the economy, causing higher inflation than rule-based monetary policy (Barro and Gordon, 1983). In sum, procyclical capital flows tend to generate booms with low inflation, followed by recessions with inflationary pressures, reducing the room for monetary authorities to maneuver with truly countercyclical policies. So long as interest rates are procyclical, central banks have limited capacity to manage rates in a countercyclical fashion and may actually reinforce the procyclicality of capital flows and generate exchange rate volatility.
} 
entrepreneurs - agents who lack a credit history - are typically minimal in microstates. The asset price channel is likely to be minuscule because the stock market and housing are relatively illiquid, minimizing the potential wealth effect. Moreover, contracts are often denominated in foreign currency, so that their value in domestic currency changes one-forone with exchange rate changes, meaning that domestic prices are quasi-dollarized. In these circumstances, monetary policy affects the economy mainly through its impact on the exchange rate. In other words, because monetary policy will be driven by exchange rate considerations, it cannot be used proactively to influence economic activity.

In microstates, the volatility of the exchange rate can be excessive because foreign exchange markets are illiquid. As the foreign exchange (FX) market for domestic currencies in microstates is often narrow and illiquid, it is subject to spikes if a large transaction takes place. ${ }^{16}$ The damage to trade of large exchange rate fluctuations, which raise risks for exporters, is also not to be underestimated. As a result, floating exchange rates in microstates are likely to become de facto fixed over time, with the authorities intervening to smooth fluctuations. ${ }^{17}$ In principle, this problem could be avoided by hedging. But the currency of a microstate often cannot be hedged in the forward market because the market mostly does not exist. This reflects the shallow FX market, high transaction costs, and limited demand, because goods are typically invoiced in only a few currencies: U.S. dollars, euros, yen, and in some regions the local currency of the dominant player, such as the South African rand in Southern Africa and the Australian dollar for the Pacific region. In these cases a pegged exchange rate is equivalent to the government hedging on behalf of the private sector.

Moreover, the minimal credibility of central banks in microstates and their ineffective monetary policy results in "fear of floating" (see Calvo and Reinhart, 2002) caused by high exchange rate pass-through and high dollarization (and hence balance sheet effects). The fear of a large pass-through following nominal exchange rate depreciation is real in microstates (Imam, 2008). The composition of imports and exports is one factor explaining the high passthrough and hence the ineffectiveness of exchange rate depreciation in adjusting to real shocks. A disproportionately large amount of imports is made up of necessities like food and fuel, demand for which tends to be inelastic. Because these necessary imports are usually not produced domestically, inflation rises automatically with currency depreciation precisely because, unlike in diversified economies, there is no possibility of domestic substitution. Similarly, in most microstates, service-related exports, such as tourism and banking, are typically invoiced in a foreign currency (usually U.S. dollars or euros), so that depreciation

\footnotetext{
${ }^{16}$ This can create exchange rate risks because exchange rates are sensitive to small inflows, since FX markets for currencies of microstates are lightly traded. For example, the FX market in the Seychelles rupee in early 2009 is about US\$300,000 per day. This means that large FDI projects can lead to large swings of the FX market.

${ }^{17}$ A further critique of floating exchange rate is that excessive exchange rate volatility cannot be fully explained by macroeconomic fundamentals, and that volatility has inhibited international trade (Flood and Rose, 1995, and Klein and Shambaugh, 2007). Also, foreign direct investment might suffer because investors prefer exchange rate certainty when investing in new facilities.
} 
will not make exports cheaper for foreigners and will thus not stimulate the export sector. ${ }^{18}$ Another aspect of the fear of floating is that shallow domestic markets mean that most microstates are unable to borrow long-term in domestic currencies. ${ }^{19}$ As a result, companies and governments in microstates are forced to borrow abroad in foreign currencies, leading to dollarization of liabilities. In these circumstances, a sharp depreciation of the local currency will lead to severe balance sheet mismatches; the cost of external debt will rise markedly, leading to a fall in net worth. In these circumstances, a flexible exchange rate has balance sheet effects. This is why in microstates de jure floating exchange rates often become de facto fixed.

In microstates, arguably, real wages are rigid downwards, making devaluation ineffective. One explanation is that workers in economies subject to large external shocks need more protection against the shocks, as the economy is less diversified. This can happen either because government spending has a risk-reducing role in economies exposed to a significant amount of external risk (e.g., price controls and subsidies) or because institutions and policies ensure that devaluations are matched by a wage increase to make up for the real wage cut (see Rodrik, 1998). The beneficial effects of a devaluation where real wages are rigid will thus be short-lived. There is anecdotal evidence in microstates that real wages do not fall much for long periods of times after devaluations, and that wages, especially in the public sector, catch up rapidly in real terms to the pre-determined level.

To summarize, there are structural features peculiar to microstates that explain why the benefits of floating the exchange rate are few.

\section{B. Advantages of Hard Pegs in Microstates}

Against this background, the economic structure of micro-states explains why choosing a flexible exchange rate has major disadvantages (need for a costly central bank, limited gains from exchange rate flexibility, limited independent monetary policy, high exchange rate volatility). Is a fixed exchange rate therefore optimal for microstates?

A sound fixed currency - dollarization, currency board, fixed exchange rate-fulfills all three functions of money: it acts as a medium of exchange, a store of value, and a unit of account.

Moreover, as argued previously, microstates mostly do not fulfill the Marshall-Lerner condition, which states that when imports and exports are elastic, changing the exchange rate

\footnotetext{
${ }^{18}$ Another way of formulating this problem is that in microstates, the share of tradables in the Consumer Price Index is higher than in bigger countries. Moreover, the non-tradable sector is very small. Both of these imply that an independent monetary policy will place a high weight on the exchange rate, and independent monetary policy will therefore have limited advantage in providing macroeconomic stability over a hard peg.

${ }^{19}$ Fiscal dominance is probably not as much of a problem in microstates as in other countries. Because financial markets in most microstates lack depth, they have limited capacity to absorb government debt even when forced to through moral suasion or by law. This makes it difficult to monetize debt, which is mostly in foreign currency.
} 
can lead to large changes in the trade balance. This adjustment mechanism is an important characteristic for countries that are subject to frequent shocks. In fact, most microstates are specialized in a few services (typically tourism and banking) or a few goods (typically tropical fruits), demand for which is relatively inelastic. At the same time, imports are largely composed of necessities, from fuel to food, demand for which is highly inelastic. In this case, a flexible exchange rate does not help absorb shocks because there is virtually no ability to substitute imports with domestically produced inputs. After devaluation, import prices go up and there is no substitution effect, only an income effect. Often, because these tradables are inputs into nontradables, domestic inflation goes up as well, in extreme cases triggering an inflation spiral. In larger diversified economies producers using foreign inputs will replace them with domestically produced inputs, so inflation does not rise much with currency depreciation. Therefore in microstates, a floating exchange rate is unlikely to act as a shock absorber. $^{20}$

By fixing the exchange rate, a hard peg benefits microstates by allowing them to import credibility. Fixed exchange rates are seen as providing a nominal anchor that lowers inflationary expectations and helps the central bank achieve the inflation objective. It also avoids the time-consistency problem. If exit costs - political or economic - are very high, it becomes optimal for the government ex ante to ensure the sustainability of the regime. Another reason hard pegs are popular is that they contribute to policy discipline and, therefore, credibility. Unlike a float, a hard peg will be less beholden to short-term political interests or industry lobbying: In many microstates well organized and vocal manufacturing industries like textiles will be tempted to pressure the monetary authorities to depreciate the currency during tough times, taking hostage the general interest of the country. With a hard peg this cannot be done easily without opposition from competing interests that would suffer from a devaluation.

Microstates are probably too small to satisfy the criterion of optimum currency area (OCA) themselves. While a microstate might not be an OCA with the US\$/euro or other regions (no labor mobility, huge transportation costs limiting arbitrage of tradable goods, real wage rigidities), an independent currency for a small country might also mean it is not an OCA itself (see Ghosh and Wolf, 1994). According to the OCA literature, a country should peg to the currency of a country to which it is highly integrated and with which it is synchronized. We know from the work of Mundell that countries whose economic structures and trade linkages are high (wage flexibility, price flexibility, synchronized business cycles, similar real shocks, possibility of fiscal transfer) satisfy the condition of an OCA. ${ }^{21}$ Microstates are

\footnotetext{
${ }^{20}$ Devaluation is probably not a flexible instrument. Used once, it could affect the expectations of economic agents in a way that makes it more difficult to use in the future. Moreover, in emerging markets in recent years devaluations have often been contractionary because of balance sheet effects.

${ }^{21}$ Other factors, notably political considerations, also matter. Goodhart (1995) states that most countries are not OCAs even if they have recently created territorial currencies; he suggests that an OCA has "relatively little predictive power" (p.452) in explaining the creation of currencies.
} 
often so integrated with the former colonial power or regional partner that they form an OCA with them.

Having now reviewed the advantages of hard pegs, we will illustrate that not all hard pegs are alike. Let us look at all three types in turn to explore their characteristics and the pros and cons from a microstate perspective.

\section{Why Do Microstates Choose a Given Form of Hard Peg?}

\section{A. Dollarization ${ }^{22}$}

Dollarization occurs when a country keeps a foreign currency as the legal tender (we will use "dollarization" throughout, even if the foreign currency is the euro or another currency). This is the most credible form of hard peg. We will look only at cases of official dollarization, where a foreign currency replaces a national currency as a legal tender (see Table 1). Which countries have dollarized? Several factors stand out:

Full dollarization has been an exchange regime choice for centuries. Dollarization has existed at least since the 13th century, though most cases took place between the end of the 19th century, around World War I, and during World War II-periods when many microstates gained their independence.

Most dollarized economies are the result of political rather than purely economic circumstances. While with independence these states decided to become politically independent, essentially they remained economically dependent on the former colonizing country. By deciding to keep a foreign currency as legal tender, the newly independent states did not necessarily expect large economic gains - though some were far from negligible (see below). Instead, the new states realized that a national currency based on fiduciary forms of money could not be created until the state could gain enough credibility for people to have confidence in the new currency - a time-consuming and potentially costly process. Dollarization was thus seen as a shortcut to achieving a viable currency at little cost.

The vast majority of microstates that dollarized have small populations, typically fewer than 150,000. Because economies of scale apply in setting up a public body such as a central bank, it does not make economic sense for very small countries to have one. The required institutional infrastructure to operate monetary policy - the necessary starting capital, skilled staff, data collection capacity, etc., - can be problematic and costly for countries with small populations. Most independent states that are small initially continued to share the currency of the former colonial power, essentially outsourcing exchange rate and monetary policy. ${ }^{23}$

\footnotetext{
22 This section draws on Imam (2009).

${ }^{23}$ Moreover, if a microstate is dollarized and has emigrants to the US, this creates more labor mobility and makes dollarization work better than say a country without this type of international labor mobility.
} 
The choice of a foreign legal tender tends to be based on geographical considerations or trade links. For these reasons, former French territories use the euro, Danish territories the Danish krone, and U.S.-administered trusteeships the dollar. In the Pacific, countries that were formerly British-controlled now use either the New Zealand or the Australian dollar.

Dedollarization has been the exception, not the rule. With the notable exception of Liberia (not a microstate so not represented in Table 1) in 1983, there is no precedent for de jure dedollarizing. This suggests that dollarization is difficult to reverse, which makes it a credible exchange rate arrangement. Thus interest in dollarization arises precisely because it is so difficult to reverse and hence credible.

Table 1: List of Dollarized Micro-States

\begin{tabular}{|c|c|c|c|}
\hline Country & Population Political StatU.S. & Currency U.S.ed & Introduction of Currency \\
\hline Andorra & 63,000 Independent (1278) & French France and Spanish Peseta & $1278($ since 1999 Euro $)$ \\
\hline Channel Is lands & 140,000 British dependencies & Pound sterling & 1797 \\
\hline Greenland & 56,000 Danish self-governing region & Danish krone & Before 1800 \\
\hline Pitcairn Is land & 56 British dependency & New Zealand dollar and U.S. dollar & $1800 \mathrm{~s}$ \\
\hline Saint Helena & 6,000 British colony & Pound sterling & 1834 \\
\hline Monaco & 30,000 Independent (1419) & French France and Spanish Peseta & 1865 (since 1999 Euro) \\
\hline Tuvalu & 10,000 Independent (1978) & AU.S.tralian dollar & 1892 \\
\hline San Marino & 24,000 Independent (301) & Italian Lira & 1897 (since 1999 Euro) \\
\hline Guam & 150,000 U.S. territory & U.S. dollar & 1898 \\
\hline Samoa, American & 60,000 U.S. territory & U.S. dollar & 1899 \\
\hline Norfolk Is land & 2,000 AU.S.tralian external territory & AU.S.tralian dollar & Before 1900 \\
\hline Niue & 2,000 New Zealand self-governing Territory & New Zealand dollar & 1901 \\
\hline Nauru & 8,000 Independent (1968) & AU.S.tralian dollar & 1914 \\
\hline Virgin Islands, U.S. & 100,000 U.S. territory & U.S. dollar & 1917 \\
\hline Liechtenstein & 31,000 Independent (1866) & Swiss France & 1921 \\
\hline Tokelau & 1,600 New Zealand territory & New Zealand dollar & 1926 \\
\hline Vatican City & 1,000 Independent (1929) & Italian Lira & 1929 (since 1999 Euro) \\
\hline Kiribati & 80,000 Independent (1979) & AU.S.tralian dollar & 1943 \\
\hline Marshall Is lands & 60,000 Independent (1986) & U.S. dollar & 1944 \\
\hline Micronesia & 120,000 Independent (1986) & U.S. dollar & 1944 \\
\hline Northern Mariana Is lands & 48,000 U.S. Commonwealth & U.S. dollar & 1944 \\
\hline Palau & 18,000 Independent (1994) & U.S. dollar & 1944 \\
\hline Cocos (Keeling) Is lands & 600 AU.S.tralian external territory & AU.S.tralian dollar & 1955 \\
\hline Turks and Caicos Is lands & 14,000 British colony & U.S. dollar & 1973 \\
\hline Virgin Islands, British & 17,000 British dependency & U.S. dollar & 1973 \\
\hline CyprU.S., Northern & 180,000 de facto independent & Turkish Lira & 1974 \\
\hline Timor-Leste & 1.1m Independent (2002) & U.S. dollar & 2002 \\
\hline Montenegro & 680,000 Independent (2006) & Euro & 2006 \\
\hline
\end{tabular}

Few studies as yet have compared cross-country evidence of the economic performance of dollarized and nondollarized economies, reflecting in part the difficulty of finding an appropriate control group. One notable exception is Edwards and Magendzo (2001). Using the matching estimator technique on a data-set for 199 countries covering 1970-98, they find that dollarized countries have a lower growth rate than nondollarized countries even though their inflation is much lower. They speculate that one reason for this might be that dollarized 
economies have difficulty in accommodating external shocks compared to countries with weaker exchange rate regimes. ${ }^{24}$

\section{B. Currency Board Arrangements}

Currency board arrangements (CBAs) are considered the second most robust and credible exchange rate system after dollarization. In a CBA all notes and coins (and all banks that are creditors of a reserve account at the currency board) must be backed by foreign currency reserves to guarantee that they can be converted into the reserve currency (usually more than 100 percent of the monetary base, to maintain a margin of protection in case the reserve currency the CBA holds loses value). Thus a CBA maintains unlimited convertibility between its notes and coins and the currency against which they are pegged (the anchor currency) at a fixed rate of exchange, with no restrictions on current-account or capitalaccount transactions (see Hanke, 2002). In theory, therefore, the peg with the foreign currency tends to keep interest rates and inflation very closely aligned to those in the country that issues the anchor currency. Productivity differences arising from different levels of development between the CBA and the anchor country (Balassa-Samuelson effect) could though lead to higher inflation rates.

CBAs have at one time existed in over 70 countries most of them microstates (see Wolf et al., 2008). ${ }^{25}$ The CBA was developed by the U.K. government so that colonies could have a strong currency and facilitate trade while keeping some seignorage revenue. It was also a response to the problem of transporting currencies across oceans (see Schwartz, 1993).

The first successful attempt to establish a currency board (not entirely orthodox in its early years) occurred in Mauritius in 1849. After some experimentation the system achieved its orthodox form with the West African Currency Board, established in 1912 for the colonies of Nigeria, the Gold Coast (Ghana), Sierra Leone, and the Gambia. By the 1930s currency boards were widespread in British colonies in Africa, Asia, the Caribbean, and the Pacific islands. Outside British colonies they were less popular but still present. ${ }^{26}$ Over the $1990 \mathrm{~s}$,

\footnotetext{
${ }^{24}$ Note that the studies do not discuss whether dollarized economies have lower volatility or not; it could be the case that the welfare cost of slower growth could be offset by the welfare benefits from lower volatility, thereby reinforcing the case for dollarization.

${ }^{25}$ The gold standard was a special case of a currency board where the value of the national currency was linked to the value of gold rather than a foreign currency. The idea of currency boards originated in Britain in the early 1800 s among a group of economists known as the "Currency School" that had great political influence. The Bank Act of 1844 was intended to convert the Bank of England into a currency board. Unlike modern advocates of currency boards, though, the Currency School did not realize that both deposits and notes that comprise the monetary base has to be backed 100 percent with foreign assets in a currency board system. Because the Bank Act had no reserve requirement for deposits, instead of converting the Bank of England into a currency board, the act converted it into a central bank. Because Britain was the most economically advanced country of the time, its example was influential, and many other countries imitated the British legislation (see Helleiner, 2004).

${ }^{26}$ Currency boards also existed in independent countries as diverse as Argentina in the early 1900 s, the free city of Danzig in the 1920s, and Yemen, but most of the long-term successes have been in microstates (see Wolf et al., 2008).
} 
after adoption by Argentina, CBAs had a temporary revival in microstates like Estonia. Other countries, particularly during crisis (e.g., Russia and Indonesia) also contemplated a CBA.

The following observations about microstates and CBAs are notable (see Table 2):

Although CBAs started in 1849, they really spread in microstates only between 1930 and the $1960 \mathrm{~s}$. The CBA system reached its greatest extent in the late 1940s, when about 50 countries all had such arrangements.

Most CBA arrangements in microstates occurred in British colonies. This could reflect both the support by the Bank of England and the intellectual climate in British microstates favoring this sort of exchange rate arrangement.

With independence, particularly in the post-war period, microstates often abandoned CBAs for more flexible arrangements. This probably reflects the post-war belief that activist monetary policy would stimulate growth and development. Because many microstate leaders or their advisors were educated in the U.K., they absorbed the prevailing economic thinking. At the time the Keynesian revolution created an intellectual environment for proactive macroeconomic policy that was inconsistent with CBAs, requiring that the exchange rate be flexible so it could be used as an adjustment tool. Another problem is that CBAs were tainted by having been introduced in colonial times, so many countries abandoned them in the wake of independence - just as a national flag became a symbol of independence, so did an independent national currency.

The few remaining CBAs are mostly in the Caribbean, where they have been around for a long time. More recent CBAs fell victim to the intellectual fashions of the 1950s and 1960s that favored central banking.

Countries with CBAs tend to have larger populations on average than dollarized economies. While there are some notable exceptions, this could reflect the relatively high fixed costs of setting up CBAs compared to dollarized economies. It might not be worthwhile for smaller countries to have one.

CBAs worked well in practice, achieving low inflation, full convertibility into their anchor currencies, and good economic growth. Empirically, as illustrated by Wolf et al. (2008), CBAs have done well compared with other exchange rate regimes: "The evidence suggests that currency boards are indeed robustly and causally associated with lower inflation. The difference reflects both discipline effects (lower monetary growth) and credibility effects (lower inflation for a given rate of monetary growth). The better inflation performance does not come at the cost of slower growth or worse trade performance. Indeed, if anything, growth is higher than under other exchange rate regimes. While output volatility is greater than under flexible exchange rates, it is no higher than under other pegged exchange rate regimes. Finally, currency boards are not associated with any greater susceptibility to financial crisis" (p. xii). 


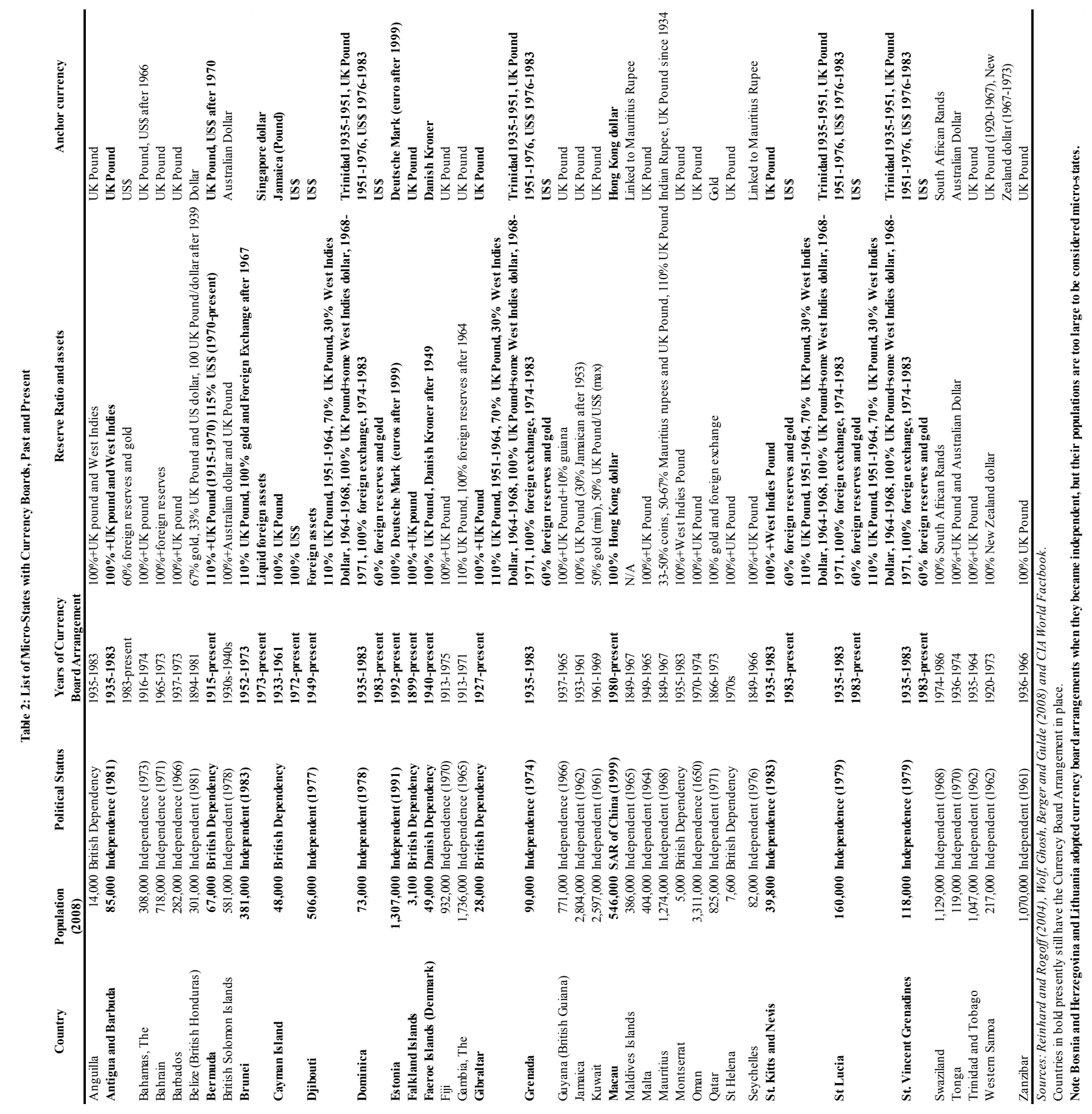

\section{Fixed Exchange Rates}

In a conventional fixed peg arrangement, a currency is pegged at a set rate to a major currency or basket of currencies, allowing the exchange rate to fluctuate within a narrow margin, typically \pm 1 percent, around a formal or de facto central rate. If the fluctuation goes 
beyond these limits the monetary authority intervenes by buying or selling its own currency on the open market (see Table 3$)^{27}$. When do microstates use fixed exchange rates? Here, it is necessary to take into account several points:

Only since the 1970s have microstates become interested in fixed exchange rate regimes. Unlike CBAs and dollarization, fixed exchange rate regimes are a relatively recent phenomenon. Few microstates adopted this arrangement before the 1970s, or after the 1980s. This could reflect the intellectual predominance during the interim of a belief among economists that developing countries needed a tight peg. Fixed exchange rates became popular in microstates after episodes of high inflation in the 1970s, when importing the credibility of an anchor country became an effective way to stabilize the economy.

In general countries adopting fixed exchange rate systems tend to have larger populations than other microstates. Most of them have at least 500,000 inhabitants, and a number have more than 1 million. It may be that a large population is needed to support the higher fixed costs of setting up the system

Fixed exchange rate regimes have appeared not only in British colonies and colonies of their former dependents, but also in French and Portuguese colonies. This could reflect an intellectual tradition prevailing in developed countries in the 1970s-80s. Cultural and educational links with the former colonial masters are still close in most microstates.

Fixed exchange rate regimes in microstates are enduring. While orderly revaluations and devaluations have taken place, pegs in microstates have rarely been attacked, even though most of them have been in place for decades. This suggests that the peg is credible and that the monetary authorities do not use the exchange rate in an activist way, as they have done in emerging markets.

To our knowledge, no scholar has looked at the economic performance of fixed exchange rates alone without considering dollarized currencies or CBAs. Ghosh, Gulde, Ostry and Wolf (1995), using a sample of 136 countries for the period 1960-90, find that in pegged exchange rate regimes "inflation has generally been lower ... than under more flexible arrangements. This result stems from two factors. First, a monetary discipline effect: fixed exchange regimes are associated with slower rates of monetary growth. Second, a confidence effect: fixed exchange rate regimes are associated with slower velocity growth ... thus yielding a lower inflation rate for a given rate of monetary expansion ... as regards growth, we find little systematic differences" (italics original) (p.2).

\footnotetext{
${ }^{27}$ Note that Table 3 includes countries that at one time had pegged exchange rates, such as Mauritius or Seychelles, but that have in recent years moved towards more flexible exchange rate regimes.
} 
Table 3: List of Micro-States that have Pegged Exchange Rate, Past and Present

\begin{tabular}{|c|c|c|c|c|}
\hline Country & Population & Political Status & Currency Pegged & Introduction of Peg to Currency \\
\hline Aruba & 104,500 & Dependency of the Netherlands & U.S. dollar & 1986 \\
\hline Bahamas, The & 308,000 & Independence (1973) & U.S. dollar & 1974 \\
\hline Bahrain & 718,000 & Independence (1971) & SDR (until 2001) now US dollar & 1980 \\
\hline Belize & $3,101,000$ & Independence (1981) & U.S. dollar & 1981 \\
\hline Bhutan & 682,000 & Independence (1907) & Indian Rupee & 1979 \\
\hline \multirow[t]{2}{*}{ Botswana } & & & South A frican Rand since independence, with period & \\
\hline & $1,842,000$ & Independence (1966) & of peg to U.S. dollar between 1976-1980 & 1980 \\
\hline Cape Verde & 427,000 & Independence (1976) & Portugese Escudo/(Euro since 1999) & 1998 \\
\hline Cayman Islands & 48,000 & British Dependency & Jamaican dollar (US dollar since 1974) & 1972 \\
\hline Comoros & 732,000 & Independence (1975) & French Franc/(Euro since 1999) & 1979 \\
\hline Cook Island & 12,300 & New Zealand Dependency & New Zealand dollar ${ }^{(1)}$ & 1972 \\
\hline Cyprus & 792,000 & Independene (1960) & Deutsche Mark (1973-1999), Euro since 1999 & 1973 \\
\hline \multirow[t]{2}{*}{ Equatorial Guinee } & & & Spanish Peseta (1969-79)/SDR (1979)/French & 1968 \\
\hline & 617,000 & Independence (1968) & Franc(1984-1998)/(Euro since 1999) & \\
\hline Gabon & $1,485,000$ & Independence (1960) & French Franc/(Euro since 1999) & 1960 \\
\hline \multirow[t]{2}{*}{ Guinea-Bissau } & & & Peg to Escudo, (1976-78), Peg to SDR (1978-1997), & \\
\hline & $1,503,000$ & Independence (1974) & Joined CFA in 1997 (FF since 1997-99; Euro since 1999) & 1997 \\
\hline \multirow[t]{2}{*}{ Iceland } & & & Peg to U.S. dollar (1944-1977), Peg to DM/Euro since & \\
\hline & 304,000 & Independence (1944) & 1983 & 1983 \\
\hline Kiribati & 110,400 & Independence (1979) & Australian dollar & 1979 \\
\hline Kuwait & $2,597,000$ & Independent (1961) & U.S. dollar & 1969 \\
\hline Lesotho & $2,128,000$ & Independence (1966) & South A frican Rand & 1966 \\
\hline \multirow[t]{3}{*}{ Luxembourg } & & & Belgium Franc (1935-40), Reichsmark (1941-44), US & \\
\hline & & & dollar (1944-55), Deutsche Mark (1955-1999), Euro & \\
\hline & 486,000 & Independence (1839) & (since 1999) & 1955 \\
\hline Maldives & 386,000 & Independence (1965) & U.S. dollar (1995) & 1965 \\
\hline Mauritius & $1,274,000$ & Independent (1968) & Pound Sterling (1967-76), US dollar (since 1976) & 1976 \\
\hline Namibia & $2,088,700$ & Independence (1990) & South African Rand ${ }^{(2)}$ & 1993 \\
\hline Netherland Antillees & 225,400 & Dependency of the Netherlands & U.S. dollar & 1940 \\
\hline Oman & $3,311,000$ & Independence (1650) & Dollar & 1974 \\
\hline Qatar & 825,000 & Independence (1971) & U.S. dollar ${ }^{(3)}$ & 1973 \\
\hline Samoa & 217,000 & Independence (1962) & New Zealand dollar & 1967 \\
\hline Solomon Islands & 581,000 & Independence (1978) & Australian dollar & 1977 \\
\hline Sao Tome and Principe & 206,000 & Independence (1975) & US dollar & 1977 \\
\hline Seychelles & 82,000 & Independence (1976) & Basket & 1967 \\
\hline St Helena & 7,600 & British Dependency & Pound Stirling & 1976 \\
\hline Suriname & 476,000 & Independence (1975) & U.S. dollar & 1994 \\
\hline Swaziland & $1,129,000$ & Independence (1968) & South A frican Rand & 1974 \\
\hline Trinidad and Tobago & $1,047,000$ & Independence (1962) & Pound Stirling (1962-76) US dollar (1976-present) & 1962 \\
\hline Tuvalu & 12,200 & Independence (1978) & Australian dollar & 1976 \\
\hline Vanuatu & 215,000 & Independence (1980) & Australian dollar & 1982 \\
\hline
\end{tabular}

\section{How Do the Different Hard Pegs Compare?}

How do the three forms of hard peg differ in their advantages and disadvantages for microstates? We will now illustrate that the three currency arrangements are mostly variations of each other, with advantages counterbalanced by disadvantages. It is not immediately clear (see Table 4) which system a microstate should prefer; much depends on country-specific factors.

Credibility is a key consideration in the choice of an exchange rate regime. Dollarization provides the hardest form of credibility, followed by CBA and a hard peg. The reason CBAs 
and hard pegs are less credible is that exit costs, in terms of the political costs for governments and the economic cost to the monetary authorities, are not as high.

\begin{tabular}{|c|c|c|c|c|}
\hline & Dollarization & Currency Board & Hard Peg & Optimum \\
\hline Credibility & Perfect & Very High & High & Perfect \\
\hline Seignorage & No & Yes & Yes & Yes \\
\hline Interest Premium & Low & Medium & High & Low \\
\hline Interest rate decision & No & No & No & Yes \\
\hline $\begin{array}{l}\text { One-off cost of acquiring } \\
\text { currency }\end{array}$ & Yes & Yes & No & No \\
\hline Reserve Coverage & N/A & $100 \%$ or more & Variable foreign reserves & No \\
\hline FX convertibility & Fully convertible & Fully convertible & Mostly fully convertible & Fully Convertible \\
\hline LOLR & No & No & Yes & Yes \\
\hline Staffing requirements & No staff & Small Currency Board Staff & Large staff & No staff \\
\hline Acquisition of Reserves & $\begin{array}{l}\text { Must Run CA surplus/inflow } \\
\text { through capital account }\end{array}$ & $\begin{array}{l}\text { Must Run CA surplus/inflow } \\
\text { through capital account }\end{array}$ & $\begin{array}{l}\text { Must Run CA surplus/inflow } \\
\text { through capital account }\end{array}$ & No \\
\hline Transaction costs & None & Low & Low & None \\
\hline Budgetary Discipline & Yes & Yes & Yes, though less strong & Yes \\
\hline Monetary Policy & None & Small (if capital markets imperfect) & Small (if capital markets imperfect) & Yes \\
\hline
\end{tabular}

Unlike CBAs and hard pegs, dollarization does not generate seignorage revenues in microstates. CBAs and hard pegs earn interest on foreign reserves (assets) and issue notes (liability), which does not carry an interest rate cost. This can be an important source of funds, particularly when a country lacks a tax collection authority to generate revenues. Annual seignorage revenue losses for a typical microstate like Cape Verde have been estimated at about 1 percent of GDP in perpetuity (see Imam, 2009). To make up for this, the government would have to increase revenues by raising taxes or cutting spending.

The interest premium on debt is in principle lowest for dollarized economies, followed by CBAs and then hard pegs. A dollarized economy will import the credibility and monetary policy of the hard currency it has adopted. Lower inflation, and lower inflation expectations, should result. Confidence that inflation will remain low should in turn lead to stable and low interest rates. While the exchange rate risk premium disappears in dollarized economies, the country risk premium does not (Imam, 2009). By eliminating the ability to monetize debt, dollarization in principle enhances budgetary discipline because deficits must be financed through higher taxes, lower expenditures, or more debt rather than by printing money. For CBAs and hard pegs, these arguments are less applicable because the risk of exiting from a CBA is high and for hard pegs even higher, thereby requiring a premium (currency risk will never be eliminated because there is always a chance of devaluation).

In theory all forms of hard peg should lead to a loss of control of monetary policy. By definition, a dollarized country and by construction a CBA do not have discretionary powers 
to affect monetary policy. ${ }^{28}$ The $\mathrm{CBA}$ is protected from political pressure and, therefore, does not lend to the government, for example. In a world where capital markets are imperfect, there is a small room for hard pegs to some limited monetary policy (see Ronci, 2009), though in most cases it is likely to be virtually insignificant to have a large effect on the economy.

A one-off cost of acquiring dollars arises if a country does not have enough foreign reserves to buy the domestic currency to dollarize, in which case it must acquire the initial stock. If the country is credit-constrained and cannot borrow reserves, it must run current account surpluses to acquire them. This might mean that the country would have to forgo the investment opportunities it might have had if it could run a current account deficit.

Alternatively, by acquiring FX through the capital and financial account via FDI inflows, a country could accumulate the necessary reserves. CBAs have a similar cost. For hard pegs, because FX coverage does not need to be 100 percent of a central bank's liabilities, the central bank does not need to hold as many dollars. When it comes to reserve coverage, while a dollarized country does not need any, coverage must be 100 percent for CBAs and less for fixed exchange rate pegs.

The institutional costs of carrying out central bank activity are lowest for dollarized countries and highest for hard pegs. Dollarized economies only need the regulatory task of the central bank; all the remaining traditional central bank activities are redundant. As the functions of a currency board are limited to issuance of notes and coins and the rules are bound by the constitution, currency boards are also simpler to run than central banks. Market forces determine the expansion of money supply: as long as it is more profitable to invest funds in the CBA than elsewhere, commercial banks will increase their loans. A CBA needs only a small and not highly trained staff. Many central banks in microstates have 200 employees; this would be close to $1 / 2$ percent of the working population for countries with less than 100,000 inhabitants. A CBA, however, can be run by a small staff of 10 people or so (see Hanke, 2002). A fixed exchange rate arrangement requires a central bank with highly skilled staff and a statistical system to collect data, a costly undertaking. Unlike a dollarized economy or a CBA, with a fixed exchange rate the central bank must have the necessary expertise because it needs to know where the economy is heading to keep its interest rate policies congruent with the peg.

Lender of Last resort (LOLR) in fixed exchange rate countries is constrained. In principle the central bank in a fixed exchange rate system can act as a LOLR. Dollarized and CBA economies do not typically have an LOLR facility because the credibility of the LOLR

\footnotetext{
${ }^{28}$ In a CBA commercial banks hold no deposits at the currency boards. Reserve currency assets are the main form of commercial bank reserves.
} 
function is usually linked to the ability to print money. Note that we need to distinguish the role of a central bank in operating a discount window to provide short-term liquidity, which is still possible in a dollarized economy and a CBA, from its role as guarantor of the stability of the financial system if there is a bank run. To provide liquidity the central bank must accumulate the necessary funds in advance or secure lines of credit with international banks, for instance, though in practice (e.g., in Argentina) these have not been very successful. While in principle this is a serious loss, in practice it has not been substantial. In fact, there have been few bank runs in countries with a CBA (Hanke, 2002). ${ }^{29}$ But neither has the LOLR function worked well, because when there is a run on the currency, the central bank needs so much FX to defend the currency that it has problems supplying liquidity to banks.

The elimination of currency risk (and exchange rate volatility) also encourages trade integration and investment, at least with the reserve country (see Antinolfi and Keister, 2001). Transaction costs tend to rise the more flexible the exchange rate is, though the difference between dollarized, CBA and fixed exchange rate are not likely to be high.

Not all microstates currently have fixed exchange rates. Some notable exceptions appeared in the 1990s (see Table 5). What is interesting is that most of them went for crawling pegs or managed floats rather than pure floats, which suggests that the exchange rate still has an important policy role for them. For instance, once Mauritius got rid of capital controls in the early 1990s, it moved from a fixed to a managed float. Seychelles, since it defaulted on its debt in 2008, has moved to a managed float. Saô Tomé and Príncipe has had a crawling peg since 1975. Iceland, which for a period had a managed float, has reverted to a more fixed form of exchange rate since the 2008 crisis and is currently contemplating what system to adopt next. These exceptions confirm the rule that microstates tend to go for fixed exchange rate regimes.

Table 5: List of Micro-States that are Non-Pegged

\begin{tabular}{|c|c|c|c|}
\hline Country & Population & Political Status & Currency \\
\hline Mauritius & $1,274,000$ & Independent (1968) & $\begin{array}{l}\text { Moved from a crawling band around the U.S. dollar in } 1992 \text { towards a managed Float over time. } \\
\text { Pegged to pound sterling/SDR, and Currency Board arrangement prior to that. }\end{array}$ \\
\hline Iceland & 304,000 & Independent (1949) & $\begin{array}{l}\text { Managed float prior to } 2008 \text { cris is (currently non-convertible) } \\
\text { Prior to that, crawling peg to Deuts che Mark, and earlier peg to U.S. dollar and UK pound. }\end{array}$ \\
\hline Sao Tome and Principe & 206,000 & Independent (1975) & $\begin{array}{l}\text { Crawling peg around U.S. dollar since } 1977 \\
\text { Portugese escudo in circulation prior to that. }\end{array}$ \\
\hline Seychelles & 86,000 & Independent (1976) & $\begin{array}{l}\text { Managed float since } 2008 \text {. } \\
\text { Prior to that, pegged to a basked of currencies. }\end{array}$ \\
\hline
\end{tabular}

Sources: Reinhard and Rogoff (2004) and CIA World Factbook

Note that some micro-states such as Guyana are de jure managed floating, but de facto pegged according to the AREAER.

\footnotetext{
${ }^{29}$ In microstates bank runs reflect less a fear of the bank going bust than depositors taking their money out to convert it into a foreign currency. In other words, bank runs are a reflection of poor macroeconomic policy, not fear of banks going under. A CBA reduces this fear considerably.
} 


\section{ECONOMETRIC ESTIMATION}

Here we estimate the determinants of different exchange rate choices. We first hypothesize factors that might help explain the choice of a hard peg exchange rate for microstates. We then illustrate certain limitations of our data-set before explaining the estimation technique used in the analysis. After describing our findings we draw some conclusions.

\section{A. Variables Used}

The translation of theoretical concepts into empirical measures is often constrained by data availability. OCA suggests that size, openness, inflation, degree of development, and financial determinants are important for the choice of exchange rate regime. However, the insights of the OCA literature are not much use here because they reflect the dichotomy between fixed and flexible exchange rates, and we are interested in the advantages and disadvantages only of different forms of hard peg. Given the peculiarities of microstates and the applicable economic theory, we hypothesize that the following variables will matter:

- Years since independence: Microstates generally had the benefit of becoming independent after most other developing countries and were able to learn from their mistakes. It became clear in Africa, for instance, that in the numerous independent countries that created their own currency (all except those in the CFA region), the currency soon lost its value, even if nominally pegged to international currencies. We expect all else being equal, that the older a country, the more likely it is to have a fixed exchange rate, followed by a CBA and a dollarized economy. Because the relationship is not necessarily linear, we will test for nonlinear effects.

- $\quad$ Population: We would expect, all else being equal, that smaller populations have harder pegs because of the large fixed costs involved in setting up an independent currency. Dollarization is likely to predominate in the smallest countries, followed by CBAs; countries with larger populations are more likely to have fixed exchange rates.

- $\quad$ Former colonial power: One striking fact is that CBAs have been most popular in former British colonies, as have been, though to a lesser extent, dollarized economies. Former French and Portuguese colonies seem to have favored hard pegs.

- $\quad$ Financial sector development: With increasingly developed financial markets, monetary policy can focus more on internal targets such as achieving full employment and keeping inflation low, and let the exchange rate float. In microstates financial markets are typically underdeveloped for lack of economies of scale. Financially less developed microstates are therefore more likely to benefit from harder pegs, though off-shore centers like the British Virgin Islands are likely to be an exception. Note that the financial literature has on occasions focused on financial sector fragility as a determinant of an exchange rate choice (e.g. large unhedged 
foreign exchange liabilities). However, given that exchange rates have hardly changed over the years in microstates, and given lack of data of unhedged foreign exchange liabilities, we are unable to test this hypothesis.

- $\quad$ Fiscal balance: We would expect that fiscal discipline, measured as the budget balance as a share of GDP, will be more prevalent in dollarized economies, than in those with currency boards and fixed pegs. Because all three forms of exchange rate should in principle have a strong disciplinary effect, the differences are only of degree and so might not differ in a statistically systemic way.

- Openness: Openness is measured by the ratio of exports and imports to GDP. Economic theory has not clarified whether more open economies are likely to have harder pegs. On the one hand, more open economies tend to prefer harder forms of exchange rates, such as dollarization, to minimize transaction costs. On the other hand, countries that are very open are probably more exposed to shocks and might therefore prefer relatively more flexible exchange rates. Our earlier discussion, however, suggests that the latter effect is likely not to be important for most microstates.

- $\quad$ Size of the economy: From our earlier discussion we would expect size to be inversely related to the hardness of the peg because there are fixed costs in setting up a CBA, or especially a central bank for a fixed exchange rate. The smallest countries could expect to have dollarized economies and the largest fixed exchange rates.

- $\quad$ Political stability: The more politically stable a country, the more we would expect it to be able to run an independent monetary policy without political interference, and hence the more likely it is that the microstate might go for a softer exchange rate peg.

Some variables - terms of trade changes, corruption, distance from main trading partner, and product diversification - were tested for but were excluded, both because they were never statistically significant and because it was not clear from a theoretical point of view why they would differ in terms of our three forms of hard pegs.

\section{B. Data Problems}

When carrying out regressions for microstates, several problems arise that are difficult to rectify:

- One major problem is data availability. Because microstates are by definition small, they often lack good national account and other statistical data for assessing economic performance. The results must therefore be interpreted with caution. 
- What data there are often are censored, because the smaller the population, the poorer the statistics tend to be. In many microstates, collecting data has a low priority, and human capital to collect and analyze it is limited. This means that we are dealing with a selection bias: the smaller the state, the more likely data are missing.

The microstates included in our study are Aruba, Andorra, Anguilla, Netherland Antilles, American Samoa, Antigua and Barbuda, Bahrain, the Bahamas, Belize, Bermuda, Barbados, Brunei Darussalam, Bhutan, Botswana, Comoros, Cape Verde, Cayman Islands, Cyprus, Djibouti, Dominica, Estonia, Fiji, Micronesia, Gabon, The Gambia, Guinea-Bissau, Equatorial Guinea, Grenada, Greenland, Guyana, Iceland, Kiribati, St. Kitts and Nevis, Kuwait, St. Lucia, Liechtenstein, Lesotho, Luxembourg, Macao, Monaco, Maldives, Marshall Islands, Malta, Mauritius, Namibia, Oman, Panama, Palau, Puerto Rice, Qatar, St. Vincent and the Grenadines, Samoa, Saô Tomé and Príncipe, Seychelles, Solomon Islands, Suriname, Swaziland, Timor-Leste, Tonga, Trinidad and Tobago, Virgin Islands (United States), and Vanuatu.

Using information on the exchange rate regime for these microstates from 1970-2006 we constructed a data set based on IMF classifications reported in the Annual Report of Exchange Arrangements and Exchange Restrictions and other sources, notably Reinhart and Rogoff (2004), Wolf, Ghosh, Berger and Gulde (2008) and the CIA World Factbook. The problem often faced by empirical studies on de jure versus de facto exchange rate regimes is less significant for microstates because in our sample they mostly overlap. This unique feature of microstates might reflect the fact that authorities often are not able to deviate from their stated objectives because they lack credibility.

\section{Estimation Technique}

To evaluate probit model likelihood functions it is necessary to calculate normal probability distribution functions. Algorithms exist for accurately calculating univariate and bivariate normal probability distribution functions but not for trivariate or higher-dimensional normal distributions. We therefore calculate multivariate normal probability distribution functions using simulation-based methods. We will use a multinomial panel model to explain the exchange rate choices of microstates. We study the regime choices of 61 microstates for 1970-2006. The model allows for three choices: dollarized economies, CBAs, and fixed exchange rates.

The panel model we use for our estimates is the Geweke-Hajivassiliou-Keane (GHK) multivariate normal simulator (see Cappallari and Jenkins, 2003, for a useful summary). The structure of such a simulator has much in common with a seemingly unrelated regression (SUR) model except that the dependent variables are multivariate indicators. 
For the GHK simulator, let $Y_{i t}, i=1 \ldots N, t=0 \ldots T$ denote the exchange rate regime choice of country $i$ in year $t$, where $Y_{i t}=0,1,2$ stands for fixed exchange rate, currency board, and dollarized exchange rate respectively.

In this model if $U_{i t j}$ is an unobserved utility that country $i$ derives in year $t$ from the exchange rate regime $j$, then countries choose their exchange rate regime by maximizing utility.

$\operatorname{Pr}\left(Y_{i j}=j\right)=\operatorname{Pr}\left(U_{i t j}>U_{i t k}\right)$ where $j, k=0,1,2$ with $j \neq k$

It is assumed that the random utility $U_{i t j}$ consists of a predetermined component $V_{i t j}$ that is linear in a vector of explanatory variables $\mathbf{x}_{i t}$, as well as a random error $\mathrm{u}_{i t j}$.

$U_{i t j}=V_{i t j}+u_{i t j}$

$V_{i t j}=\beta_{j} x_{i t}$

$u_{i t j}=\alpha_{i j}+\varepsilon_{i t j}$

where $\beta_{j}$ is a row of vector, $\alpha_{i j}$ is country-specific effects, and $\varepsilon_{i t j}$ is an error term that is independently and identically distributed (iid) across countries, years, and exchange rate regimes. In other words this multivariate probit model can be used to fit a univariate probit model for panel data allowing for a free correlation structure over time.

Since only the utility differences matter for the regime choice, we normalize $U_{i t 0} \equiv 0$ for all $i$ and $t$. Let $\alpha_{i}=\left(\alpha_{i 1}, \alpha_{i 2}\right)^{\prime}$ and assume that $\alpha_{i}$ has a bivariate normal distribution characterized by

$\alpha_{i} \approx N(0, \Sigma)$, with $\sum=\left(\begin{array}{l}\sigma_{11} \sigma_{12} \\ \sigma_{21} \sigma_{22}\end{array}\right)$

This gives us the static version of the random effects panel. We assume that $\alpha_{i}$ is iid across countries and years. Note that the random error term $u_{i t j}$ is serially correlated due to the existence of $\alpha_{i j}$.

The problem of serial correlation can be solved by including a lagged dependent variable as a control variable. This captures the idea that countries are not continuously choosing an exchange rate regime. Not controlling for this would be equivalent to assuming that the exchange rate choice was taken each year regardless of what happened the previous year, 
which is clearly unrealistic. The resultant high serial correlation would make inference problematic.

Let $d_{i t j}=\mathfrak{I}\left\{Y_{i t}=j\right\}$ be the dummy for regime $j$, with $\mathfrak{I}\{\}$ being an indicator function generating a value of unity if the statement in brackets is true, and define $d_{i t}=\left(d_{i t 1}, d_{i t 2}\right)^{\prime}$. Our specification of this dynamic model is given by

$V_{i t j}=\gamma_{j} d_{i t-1}+\beta_{j} x_{i t} \gg 0$

This specification corresponds to a first-order Markov chain in regime transition, with the coefficient vector $\gamma_{j}=\left(\gamma_{j 1}, \gamma_{j 2}\right)$ measuring the direct influence of lagged regime choice on the current decision after controlling for the influence of other facts and for country heterogeneity. The initial regime choice $t=0$ is treated as a nonstochastic constant determined by pre-sample history, which simplifies the likelihood function (see Train, 2003; see also von Hagen and Zhou, 2007 for a similar application to developing countries).

For each estimation we set the number of random draws at 30, but also test for 25 and 35; the results do not change significantly. Because we normalize the utility associated with a fixed exchange rate to zero, the coefficients reported in Table 5 indicate the qualitative impact on the utility associated with the regime $(j=1,2$, i.e., $\mathrm{CBA}$ and dollarization) relative to fixed regimes. A positive coefficient means that an increase in the variable raises the utility of regime $j$ and, hence, its probability of being adopted rather than a fixed exchange rate.

\section{Results}

Static regression results are reported in Table 6 and dynamic regression results in Table 7. Some of the variables, such as product diversification or terms of trade shocks, are not statistically significant, perhaps because most microstates have very similar structural features that make them indistinguishable from each other, and are therefore not reported. We tested for remoteness - proxied as distance between the capital of the micro-state and the capital of the currency to which the local currency was linked - with insignificant results. Our results, summarized below, suggest that the decision to go for one form of hard peg rather than another is sensitive to the structural features of microstates:

- "Years of independence" is an important determinant for the choice of exchange rate. A country is more likely to dollarize if it gained its independence a long time ago; the opposite holds for CBA, where having gained independence more recently increases the probability of adopting a currency board. This might be the case because in our sample of countries, dollarized economies tended to gain independence earlier than other countries, and CBA countries gained their independence later. Pegged exchange rate systems, on the other hand, as shown earlier, were popular with microstates that 
are neither quite young nor quite old, having become independent in the 1970s and 1980s, probably reflecting the prevailing intellectual climate when they achieved independence. After World War II, having one's own currency (and, therefore, a fixed exchange rate) was considered a sign of independence, but microstates that became independent before that or after the 1980s viewed a territorial currency as less important.

- $\quad$ Our results suggest that the less developed the financial system, the more likely a country is to dollarize, and to a lesser extent adopt a currency board. This could be a sign that countries with underdeveloped financial systems realize that they cannot make effective use of monetary policy and other internal targets. Financially less developed microstates are therefore more likely to benefit from harder pegs, whether dollarization or a CBA.

- $\quad$ Microstates with very small populations are more likely to dollarize. This probably reflects the initial one-off cost of establishing a central bank and the fixed costs of running it, which the smallest of states have preferred to outsource and instead employ their limited human capital to other economic sectors, such as commercial banking or tourism. Population size does not have a statistically significant impact on CBAs, perhaps because they are more heterogeneous in terms of population size, with some CBAs being relatively large and others relatively small. ${ }^{30}$

- $\quad$ Countries that were former British colonies, are, all else being equal, more likely to adopt CBAs. This almost certainly reflects the intellectual view prevailing at the time in Britain, the main colonizing power when these countries gained independence. Countries that dollarized were not affected by their colonial heritage, however. We tested for the origin of the former colonial power (not shown here), and did not find that it mattered.

- Openness is negatively related to the probability of dollarizing but does not appear to matter for CBAs. This is counter-intuitive-one would expect that more openness would increase the benefit of dollarization because, for instance, it minimizes transaction costs. The fact that countries with CBAs are relatively open economies could explain why this variable does not matter.

\footnotetext{
${ }^{30} \mathrm{We}$ also tested separately for the probability of how size of the economy as measured by GDP affects the exchange rate choice. We found that it is negatively correlated with dollarization and positively correlated with CBAs. Here we clearly encounter a problem of endogeneity that we cannot correct for directly. When we used as an instrumental variable lagged income per capita and GDP, the results did not change significantly. If, as it appears, among microstates the size of the economy is negatively related to the hardness of the peg, this could relate to our hypothesis that dollarization requires the least upfront cost, CBA requires some spending, and fixed pegs require much more.
} 
- $\quad$ The size of government, as measured by public consumption as a share of GDP (Pconsumption) does not increase the probability of dollarization but does increase the probability of adopting a CBA. Countries with CBAs, it thus appears, are more likely to have large governments than those with other fixed exchange rate regimes. CBA countries, unlike dollarized countries, are able to generate seignorage revenues, allowing them to have larger governments.

Table 6: Static Multinomial Probit Panel Model Estimation

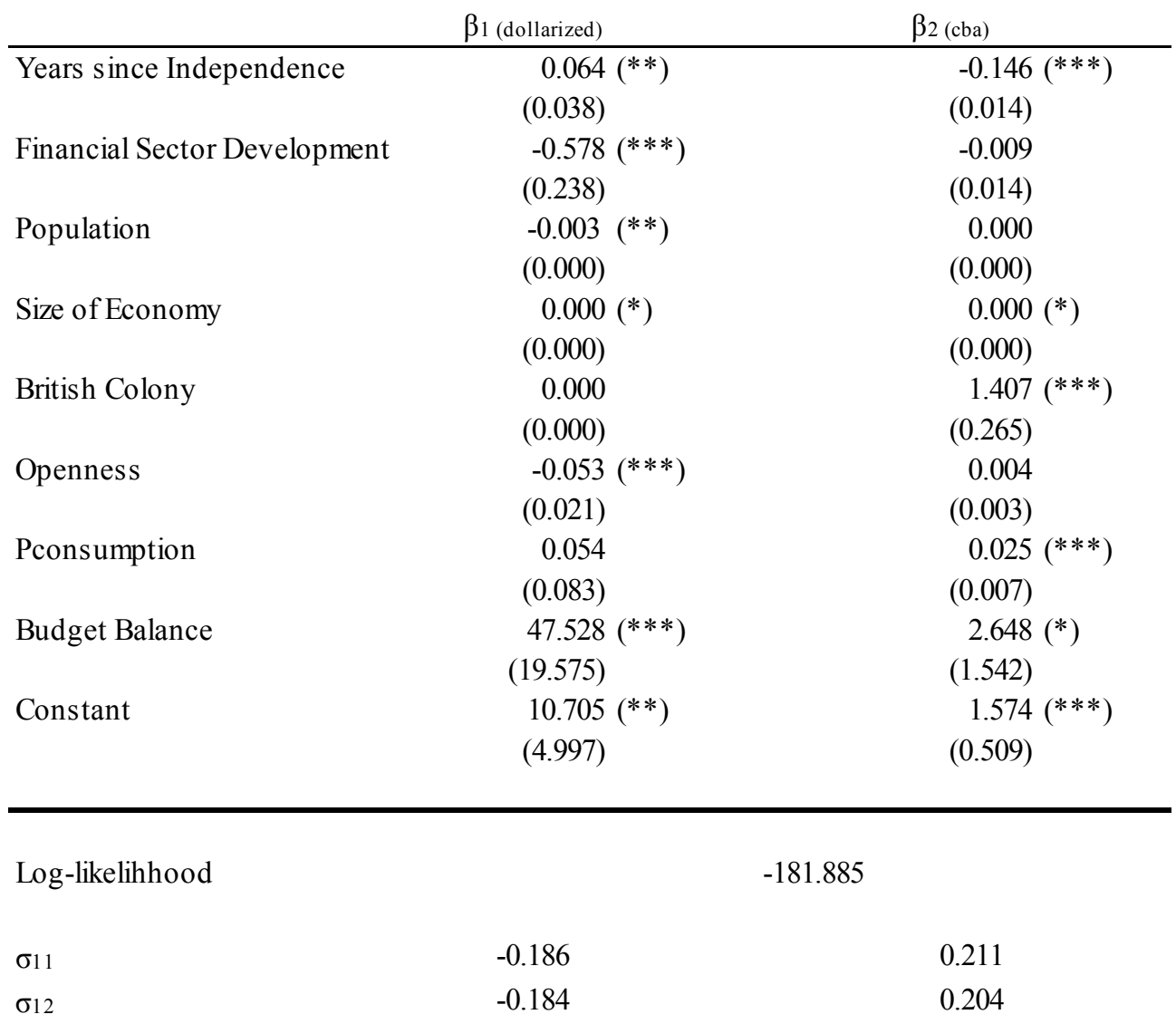

Obs. (Dollarized, CBA, Fixed ER) $517 / 655 / 1695$

$(*),(* *),(* * *)$ indicate respectively significance at 1 percent, 5 percent and 10 percent level. Constant and Period dummies not reported.

Heteroscedastic robust standard errors clustered on countries are in parentheses.

- $\quad$ Countries with more conservative fiscal policies are more likely to be dollarized, and to a lesser extent to opt for a CBA. Dollarized countries are unable to monetize debt or generate revenues through their currencies, whereas CBAs can earn seignorage. Dollarization therefore imposes a harder budget constraint than a CBA. 
A look at the dynamic multinomial probit model, adjusting for potential serial correlation, confirms the findings of the static model (Table 7). Overall, therefore, countries with CBAs tend to be former British colonies, have larger governments, and be younger than countries with fixed exchange rates. Dollarizing countries, on the other hand, are likely to be older states, have smaller population, are less likely to be open, and are more likely to have balanced budgets. Most of the variables that are statistically significant reflect structural features rather than policy variables, suggesting that exchange rate choices are constrained by microstate structural features.

Table 7: Dynamic Multinomial Probit Panel Model Estimation

\begin{tabular}{lcc} 
& $\beta 1$ (dollarized) & $\beta_{2}(\mathrm{cba})$ \\
\hline Lagged Dependent Variable & $2.425(* * *)$ & $4.693(* * *)$ \\
Years since Independence & $(0.410)$ & $(0.568)$ \\
Financial Sector Development & $0.064(*)$ & $-0.077(*)$ \\
& $(0.038)$ & $(0.046)$ \\
Population & $-0.582(* * *)$ & -0.048 \\
& $(0.238)$ & $(0.040)$ \\
Size of Economy & $0.000(* * *)$ & 0.000 \\
British Colony & $(0.000)$ & $(0.000)$ \\
& $0.000(*)$ & 0.000 \\
Openness & $(0.000)$ & $(0.000)$ \\
& 0.000 & $0.287(* * *)$ \\
Pconsumption & $(0.000)$ & $(0.077)$ \\
Budget Balance & $-0.037(* * *)$ & 0.007 \\
Constant & $(0.021)$ & $(0.009)$ \\
& 0.063 & $0.011(* * *)$ \\
& $(0.083)$ & $(0.020)$ \\
& $47.674(* * *)$ & 5.709 \\
\hline
\end{tabular}

Log-likelihhood

$-34.214$

$\begin{array}{lll}\sigma_{11} & -0.247 & 0.364 \\ \sigma_{12} & -0.242 & 0.343\end{array}$

Obs. (Dollarized, CBA, Fixed ER)

$645 / 590 / 1474$

$(*),(* *),(* * *)$ indicate respectively significance at 1 percent, 5 percent and 10 percent level. Constant and Period dummies not reported.

Heteroscedastic robust standard errors clustered on countries are in parentheses. 


\section{CONCLUSION}

We first explained the political economy of independence that characterized microstates and why most of them have gained independence only in the last 30 years. We showed that, despite the higher costs and risks faced by microstates, better accommodation of local preferences combined with a more integrated world probably explain why the benefits of independence have risen in recent times.

After showing that microstates have, at independence, chosen dollarization, CBAs, or fixed exchange rate systems rather than more flexible options, we presented possible reasons for that. Using the GHK multivariate normal simulator we estimated the determinants of each exchange rate regime in microstates and considered the policy implications. We found that while policy variables did not appear to affect the probability of choosing an exchange rate, nonetheless, CBAs tend to be former British colonies, have larger governments, and have gained independence more recently than countries with fixed exchange rates. Dollarizing countries are likely to be older states, have smaller population, are less open, and are more likely to have balanced budgets.

What are the policy implications? Microstates that gain independence will have an array of exchange rate choices to choose from, though they are likely to be constrained by structural features and their own history. The cost-benefit analysis of which form of hard peg to choose varies from one microstate to another, but limited human, institutional and financial capabilities as well as a small population will tilt the choice towards the hardest form of exchange rate, namely full dollarization. Fully outsourcing ones exchange rate policy is advisable in such a case. The benefit of moving to less hard pegs rises as a country is larger, institutionally more developed and growing rapidly. It should be noted that we have not looked at the impact of different exchange rate arrangements on the economic performance of microstates - an altogether different subject. 


\section{REFERENCES}

Alesina, Alberto, Arnaud Devleeschauwer, William Easterly, Sergio Kurlat, and Romain Wacziarg, 2003, "Fractionalization" Journal of Economic Growth, Vol. 8, pp. 15594,

Alesina, Alberto, and Enrico Spolaore, 2003, The Size of Nations (Cambridge, MA: MIT Press).

Alesina, Alberto, and Romain Wacziarg, 1998, "Openness, Country Size and the Government,” Journal of Public Economics, Vol. 69, pp. 305-21.

Antinolfi, Gaetano, and Todd Keister, 2001, "Dollarization as a Monetary Arrangement for Emerging Market Economies," Federal Reserve Bank of St. Louis, November/December, pp. 29-40.

Armstrong, H., R.J. De Kervenoael, X. Li, and R. Read, R., 1998, “A Comparison of the Economic Performance of Different Micro-states, and Between Micro-states and Larger Countries," World Development, Vol. 26, pp. 639-56.

Barro, Robert, and David Gordon, 1983, "Rules, Discretion and Reputation in a Model of Monetary Policy," Journal of Monetary Economics, Vol. 12, pp. 101-21.

Bolton, Patrick, and Gerard Roland, 1997, "The Breakup of Nations: A Political Economy Analysis," Quarterly Journal of Economics, Vol. 112, pp. 1057-80.

Calvo, Guillermo, and Carmen Reinhart, 2002, "Fear of Floating," Quarterly Journal of Economics, Vol. 117, pp. 379-408.

Cappallari, Lorenzo, and Stephen Jenkins, 2003, "Multivariate Probit Regression Using Simulated Maximum Likelihood," Stata Journal, Vol. 3, pp 278-94.

Catao, Luis, and Marco Terrones, 2000, "Determinants of Dollarization: The Banking Side," IMF Working Paper No. 146 (Washington: International Monetary Fund).

Easterly, William and Aart Kraay, 2000, "Small States, Small Problems? Income, Growth and Volatility in Small States" World Development, Vol. 28, pp. 2013-2027.

Easterly, William, and Sergio Rebello, 1993, "Fiscal Policy and Economic Growth: An Empirical Investigation" Journal of Monetary Economics, Vol. 32, pp. 417-58.

Edwards, Sebastian, and Igal Magendzo, 2001, "Dollarization, Inflation and Growth" (photocopy; Los Angeles: UCLA).

Farrugia, Charles, 1993, "The Special Working Environment of Senior Administrators in Small States," World Development, Vol. 21, pp. 221-26. 
Flood, R., and Andrew Rose, 1995, "Fixing Exchange Rates: A Virtual Quest for Fundamentals," Journal of Monetary Economics, Vol. 36, pp. 3-37.

Ghosh, Atish, and Holger Wolf, 1994, "How Many Monies? A Genetic Approach to Finding Optimum Currency Areas,” NBER Working Paper No. 4805 (Cambridge, MA: National Bureau of Economic Research).

Ghosh, Atish, Anne-Marie Gulde, Jonathan Ostry, and Holger Wolf, 1995, "Does the Nominal Exchange Rate Regime Matter?” IMF Working Paper No. 121 (Washington: International Monetary Fund).

Ghosh, Atish, Anne-Marie Gulde, and Holger Wolf, 1998, "Currency Boards: The Ultimate Fix?” IMF Working Paper No. 8 (International Monetary Fund: Washington DC)

Goodhart, Charles, 1995, "The Political Economy of Monetary Union," in Understanding Interdependence, ed by Peter Kenen (Princeton, NJ: Princeton University Press).

Frankel, Jeffrey, 1999, "No Single Currency Regime Is Right for All Countries or at All Times," NBER Working Paper No. 7338 (Cambridge, MA: National Bureau of Economic Research).

Hanke, Steve H., 2002, “On Dollarization and Currency Boards: Error and Deception," Journal of Policy Reform, Vol. 5 (No. 4), pp. 203-22.

Helleiner, Eric, 2004, The Making of National Money: Territorial Currencies in Historical Perspective (Ithaca, NY: Cornell University Press).

Hines, James, and Lawrence Summers, 2009, "How Globalization Affects Tax Design," NBER Working Paper No. 14664 (Cambridge, MA: National Bureau of Economic Research).

Imam, Patrick, 2008, "Rapid Current Account Adjustments: Are Microstates Different?" IMF Working Paper No. 233 (Washington: International Monetary Fund).

Imam, Patrick, 2009, "Introducing the Euro as Legal Tender-Benefits and Costs of Eurorization in Cape Verde," IMF Working Paper (forthcoming) (Washington: International Monetary Fund),

Klein, Michael, and Jay Shambaugh, 2006, "Fixed Exchange Rates and Trade," Journal of International Economics, Vol. 70, pp. 359-83.

Laidler, David, 1982, Monetarist Perspectives (Cambridge, MA: Harvard University Press).

McCallum, John, 1995, "National Borders Matter: Canada-US Regional Trade Patterns," American Economic Review, Vol. 85, pp. 615-23. 
Mishkin, Frederic, 1999, "International Experiences with Different Monetary Policy Regimes," NBER Working Paper No. 7044 (Cambridge, MA: National Bureau of Economic Research).

Ocampo, José Antonio, Codrina Rada, and Lance Taylor. 2008, "Economic Policy, Structure and Growth in Developing Countries: A Structuralist Approach," Initiative for Policy Dialogue

Reinhart, Carmen and Kenneth Rogoff, 1994, "The Modern History of Exchange Rate Arrangements: A Reinterpretation" Quarterly Journal of Economics, Vol. 119, pp.148

Rodrik, Dani, 1998 "Why Do More Open Economies Have Bigger Governments?" Journal of Political Economy, Vol. 106, pp. 997-1032.

Rogoff, Kenneth, Aasim Husain, Ashoka Mody, Robin Brooks, and Nienke Oomes, 2003, "Evolution and Performance of Exchange Rate Regimes," IMF Working Paper No. 243 (Washington: International Monetary Fund)

Rose, Andrew, 2000, "One Money, One Market: The Effect of Common Currencies on Trade," Economic Policy, Vol. 30, pp. 7-33.

Ruggie, John, 1993, "Territoriality and Beyond: Problematizing Modernity in International Relations," International Organization, Vol. 47, pp. 139-74.

Schuler, Kurt. 1992. "The World History of Free Banking." pp. 7-47 in The Experience of Free Banking, ed. by Kevin Dowd (London: Routledge).

Schwartz, Anne, 1993, "Currency Boards: Their Past, Present, and Possible Future Role," Carnegie-Rochester Conference Series on Public Policy, Vol. 39, pp. 147-88.

Train, Kenneth, 2003, Discrete Choice Methods with Simulation (Cambridge: Cambridge University Press).

von Hagen, Juergen and Jizhong Zhou, 2007 "The Choice of Exchange Rate Regimes in Developing Countries: A Multinomial Panel Analysis" Journal of International Money and Finance, Vol. 26, pp. 1071-1094.

Wolf, Holger, Atish Ghosh, Helge Berger, and Anne-Marie Gulde, 2008, Currency Boards in Retrospect and Prospect (Cambridge, MA: MIT Press). 


\section{APPEndiX. Summary OF Micro-States}

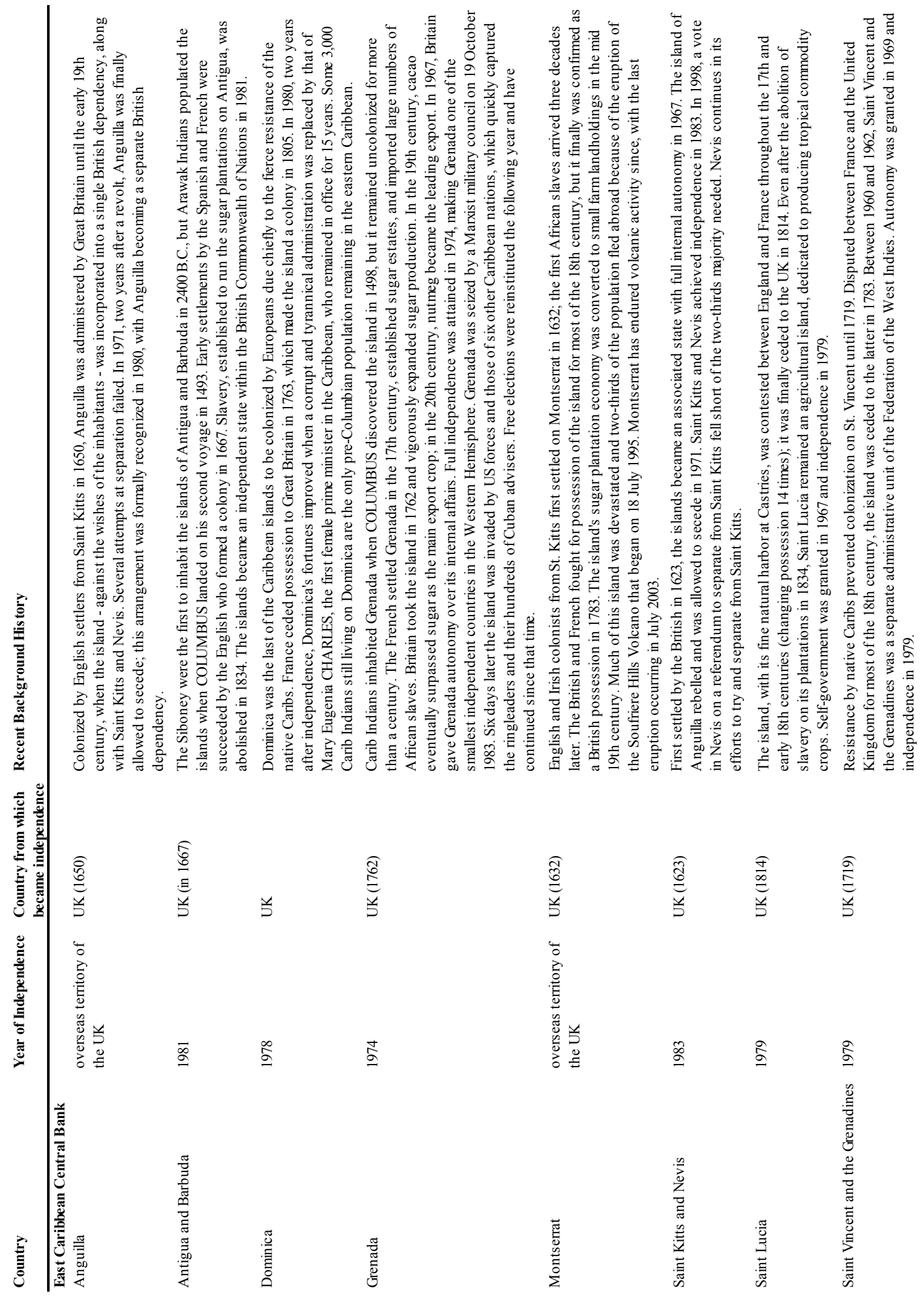




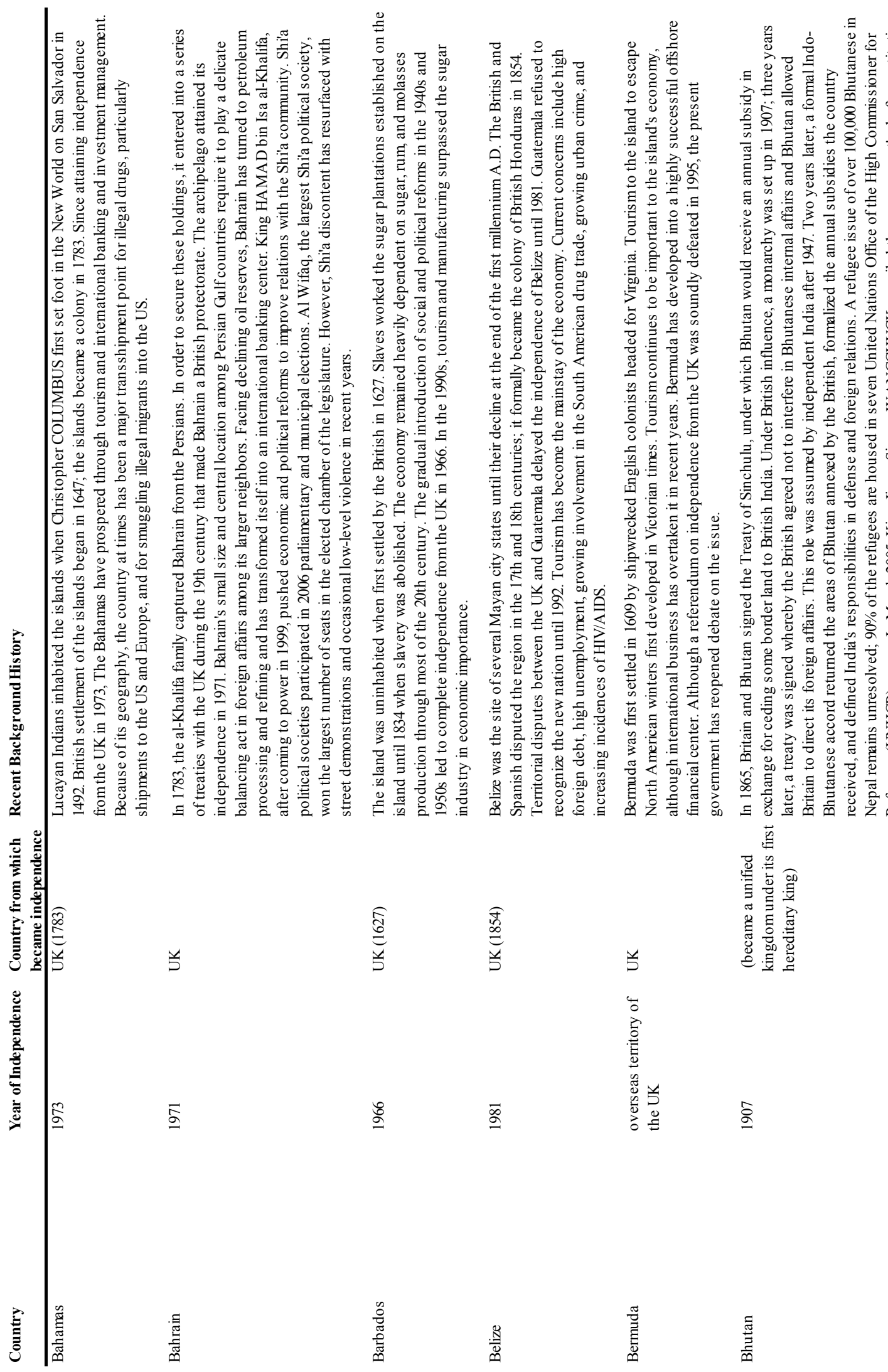




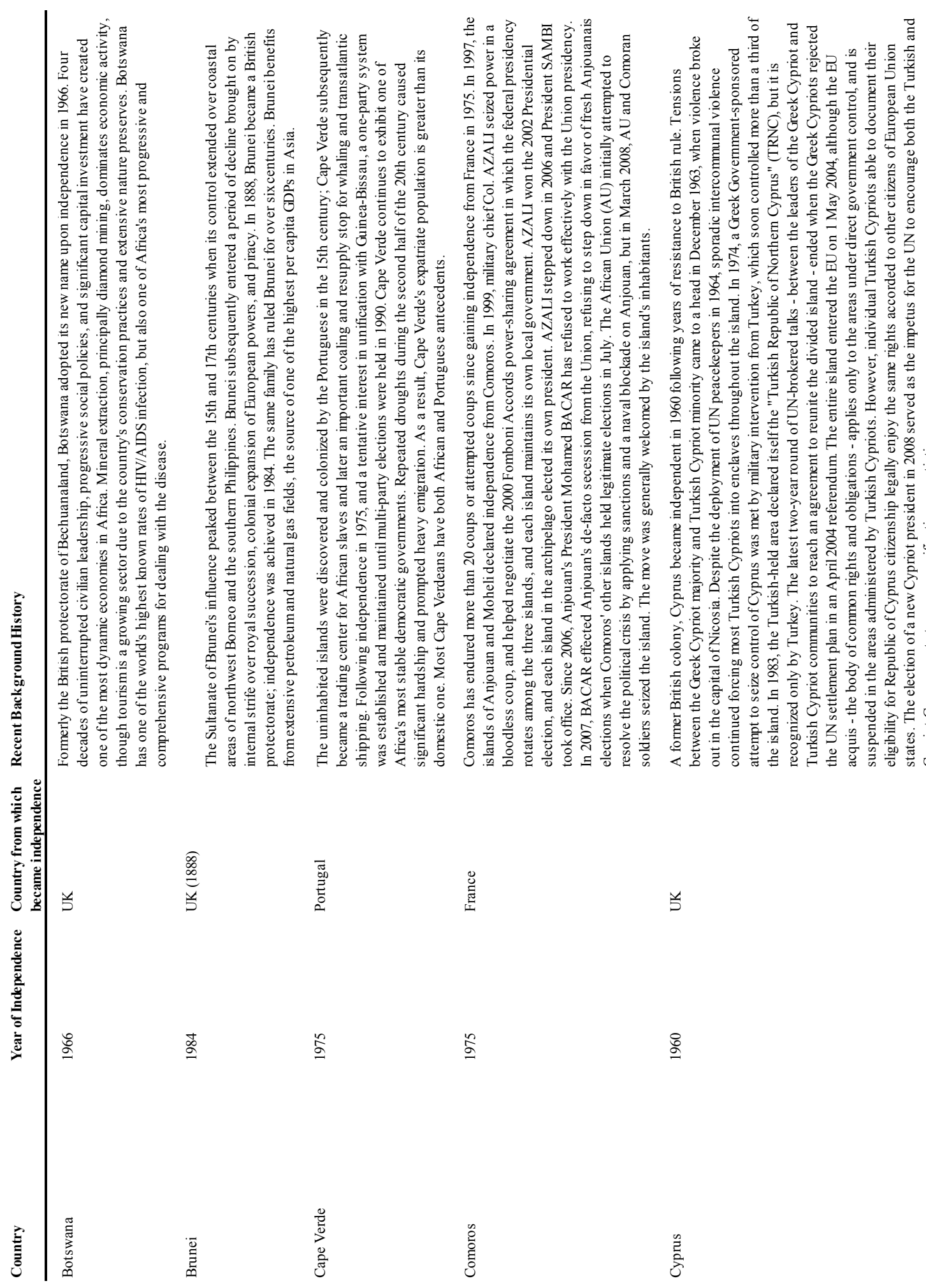




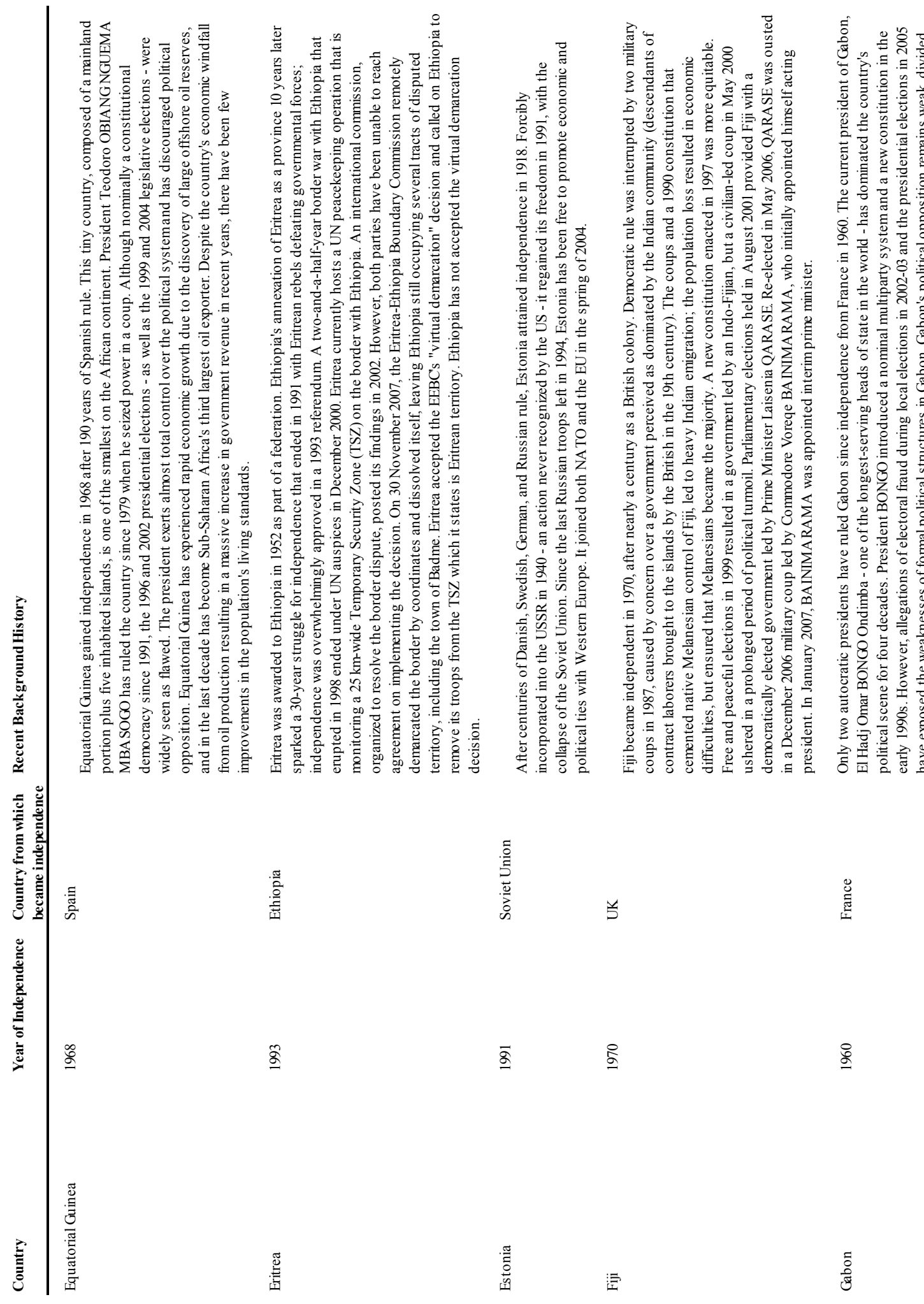




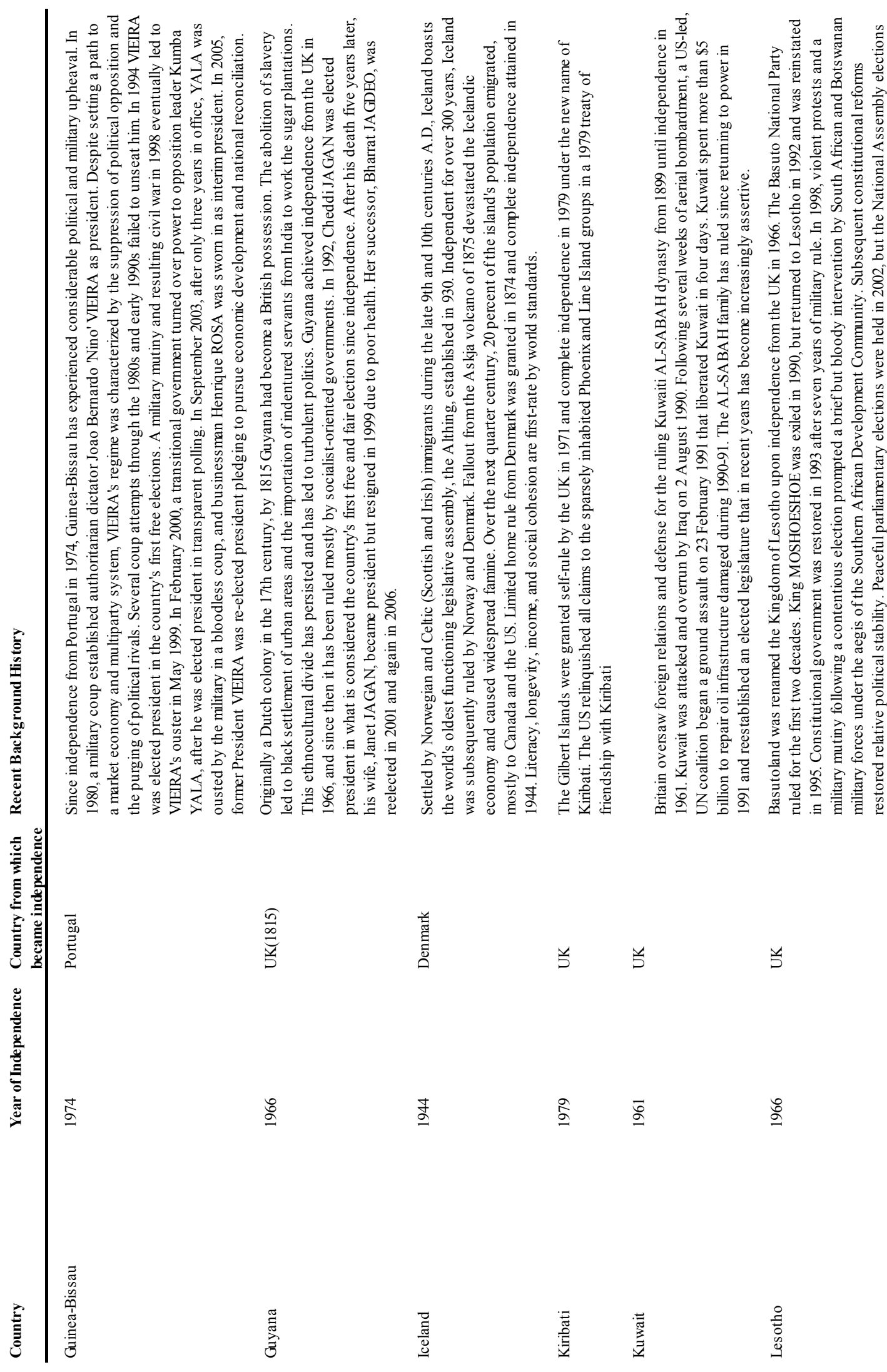




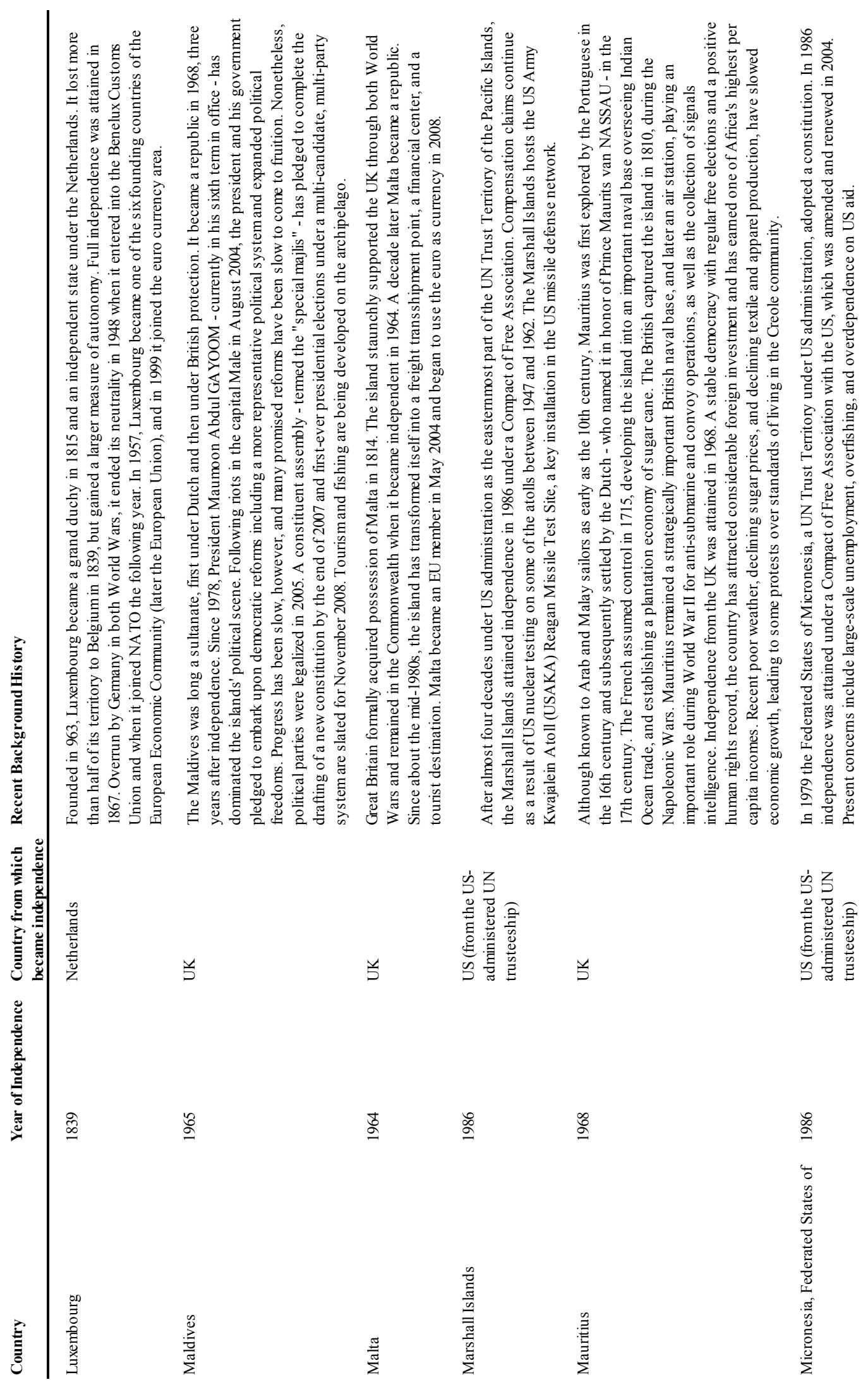




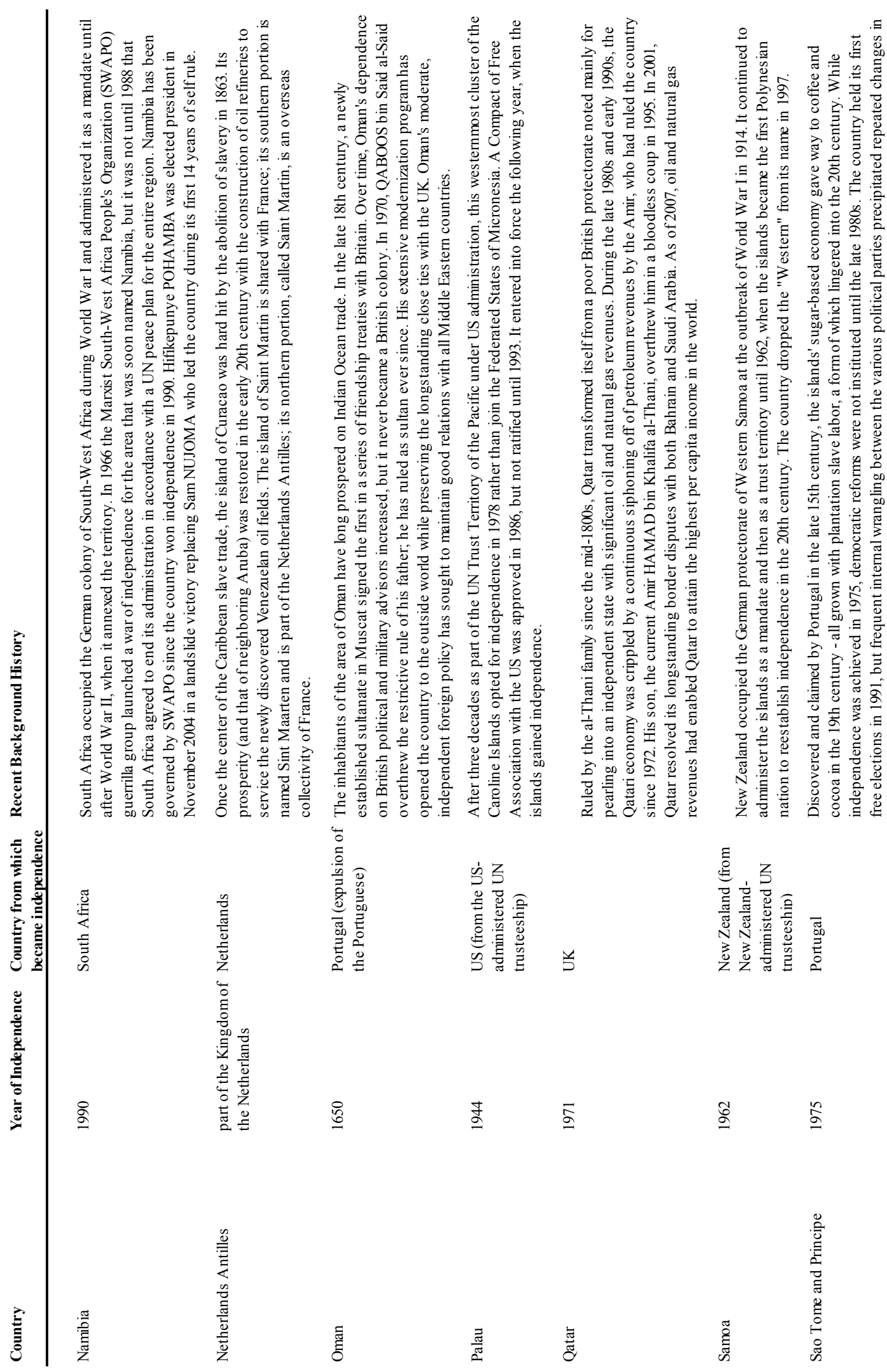




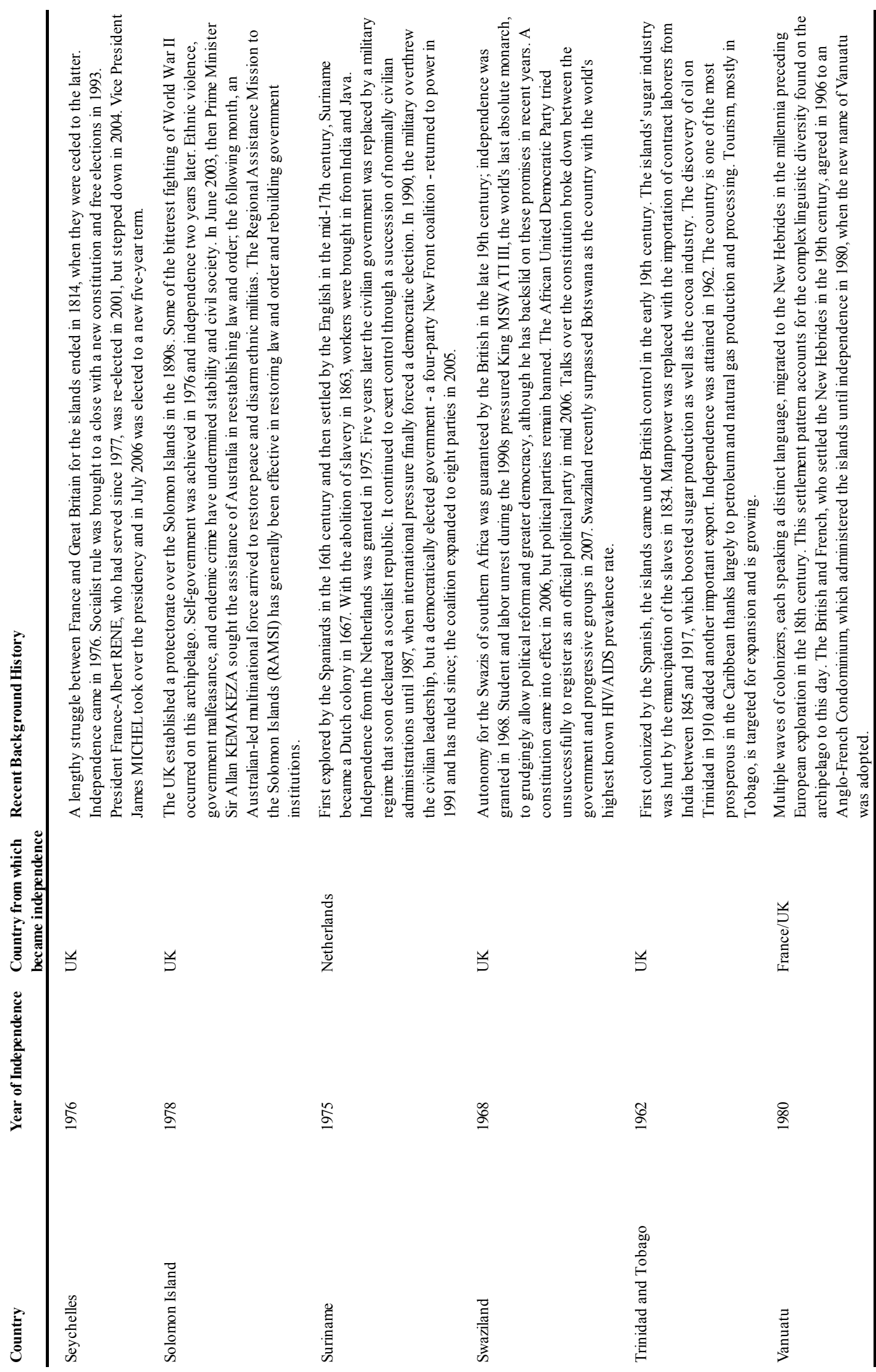

